\title{
LEVEL II SCOUR ANALYSIS FOR BRIDGE 13 (IRA-VT01330013) on STATE ROUTE 133, crossing an IRA BROOK TRIBUTARY, IRA, VERMONT
}

U.S. Geological Survey Open-File Report 96-749

Prepared in cooperation with

VERMONT AGENCY OF TRANSPORTATION and

FEDERAL HIGHWAY ADMINISTRATION 


\section{LEVEL II SCOUR ANALYSIS FOR BRIDGE 13 (IRA-VT01330013) on STATE ROUTE 133, crossing an IRA BROOK TRIBUTARY, IRA, VERMONT}

By Erick M. Boehmler and Michael A. Ivanoff

U.S. Geological Survey Open-File Report 96-749

Prepared in cooperation with

VERMONT AGENCY OF TRANSPORTATION

and

FEDERAL HIGHWAY ADMINISTRATION 


\title{
U.S. DEPARTMENT OF THE INTERIOR BRUCE BABBITT, Secretary
}

\author{
U.S. GEOLOGICAL SURVEY \\ Gordon P. Eaton, Director
}

For additional information write to:

District Chief

U.S. Geological Survey 361 Commerce Way

Pembroke, NH 03275-3718
Copies of this report may be purchased from:

U.S. Geological Survey

Branch of Information Services

Open-File Reports Unit

Box 25286

Denver, CO 80225-0286 


\section{CONTENTS}

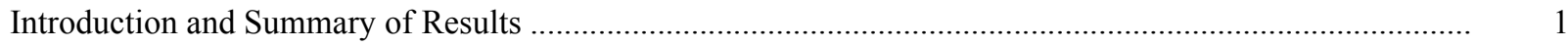

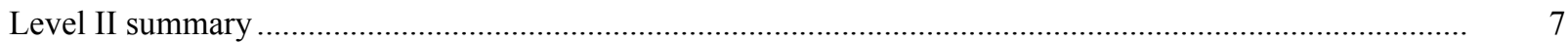

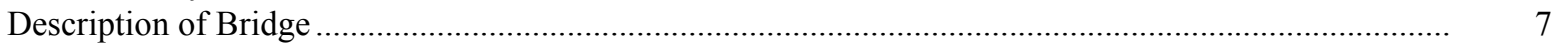







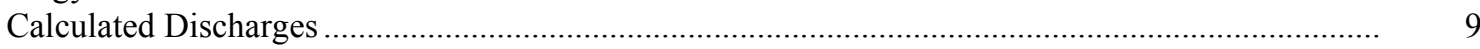

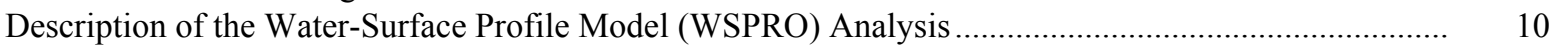



Data and Assumptions Used in WSPRO Model ...................................................................... 11

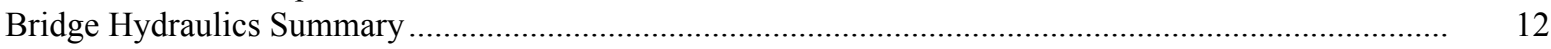

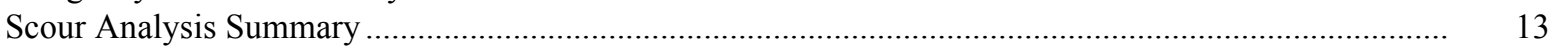

Special Conditions or Assumptions Made in Scour Analysis ...................................................... 13

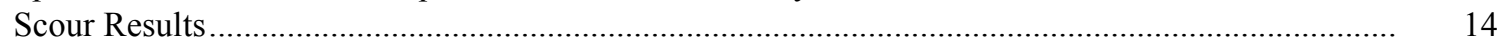

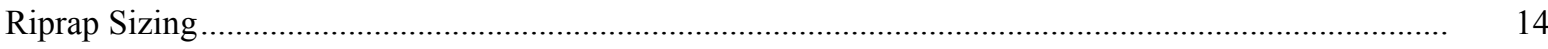

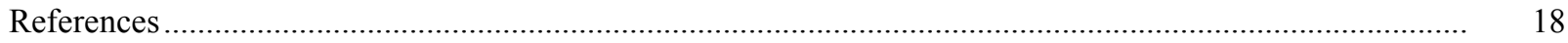

Appendixes:

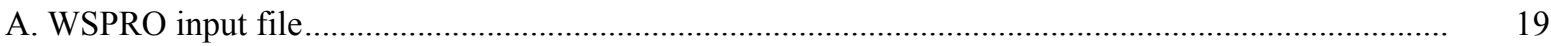





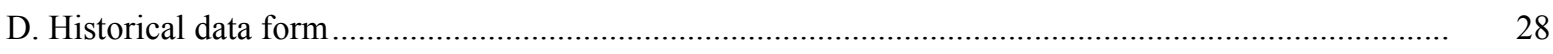

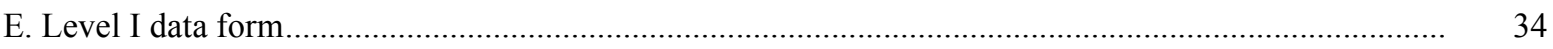

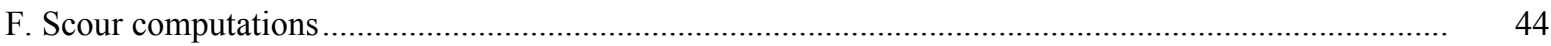

\section{FIGURES}

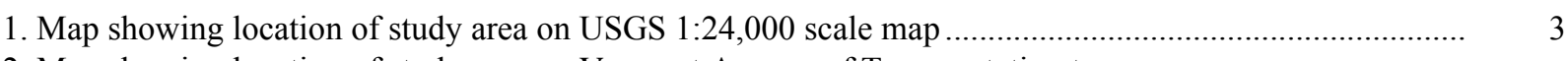

2. Map showing location of study area on Vermont Agency of Transportation town

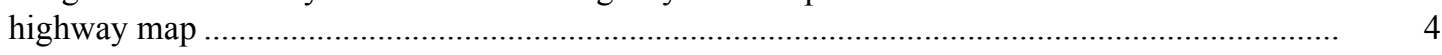

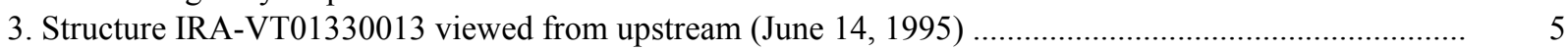

4. Downstream channel viewed from structure IRA-VT01330013 (June 14, 1995) ................................. 5

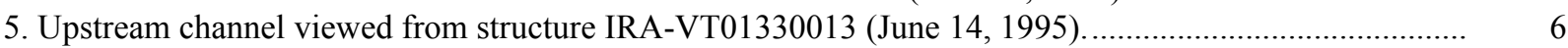

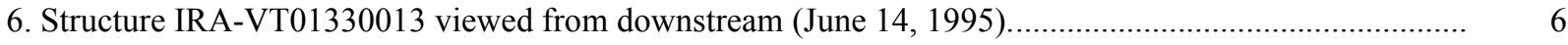

7. Water-surface profiles for the 100- and 500-year discharges at structure

IRA-VT01330013 on State Route 133, crossing an Ira Brook Tributary,

Ira, Vermont.

8. Scour elevations for the 100- and 500-year discharges at structure

IRA-VT01330013 on State Route 133, crossing an Ira Brook Tributary,

Ira, Vermont.

3

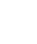

5

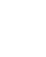

.




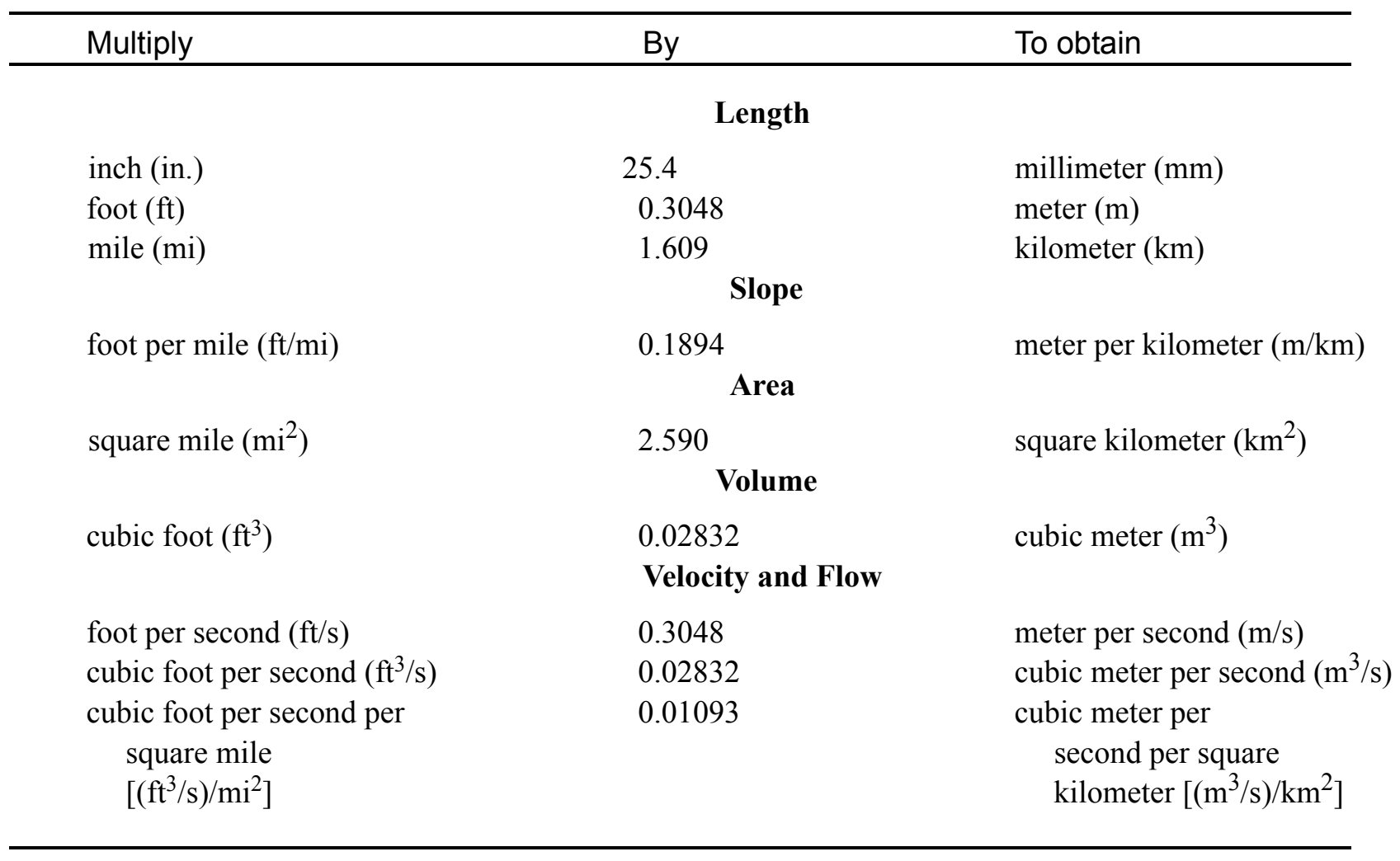

\section{OTHER ABBREVIATIONS}

$\begin{array}{lrlr}\mathrm{BF} & \text { bank full } & \text { LWW } & \text { left wingwall } \\ \mathrm{cfs} & \text { cubic feet per second } & \text { MC } & \text { main channel } \\ \mathrm{D}_{50} & \text { median diameter of bed material } & \text { RAB } & \text { right abutment } \\ \mathrm{DS} & \text { downstream } & \text { RABUT } & \text { face of right abutment } \\ \mathrm{elev} & \text { elevation } & \text { RB } & \text { right bank } \\ \mathrm{f} / \mathrm{p} & \text { flood plain } & \text { ROB } & \text { right overbank } \\ \mathrm{ft}^{2} & \text { square feet } & \text { RWW } & \text { right wingwall } \\ \mathrm{ft} / \mathrm{ft} & \text { feet per foot } & \text { TH } & \text { town highway } \\ \mathrm{JCT} & \text { junction } & \text { UB } & \text { under bridge } \\ \mathrm{LAB} & \text { left abutment } & \text { US } & \text { upstream } \\ \mathrm{LABUT} & \text { face of left abutment } & \text { USGS } & \text { United States Geological Survey } \\ \mathrm{LB} & \text { left bank } & \text { VTAOT Vermont Agency of Transportation } \\ \mathrm{LOB} & \text { left overbank } & \text { WSPRO } & \text { water-surface profile model }\end{array}$

In this report, the words "right" and "left" refer to directions that would be reported by an observer facing downstream. Sea level: In this report, "sea level" refers to the National Geodetic Vertical Datum of 1929-- a geodetic datum derived from a general adjustment of the first-order level nets of the United States and Canada, formerly called Sea Level Datum of 1929.

In the appendices, the above abbreviations may be combined. For example, USLB would represent upstream left bank. 


\title{
LEVEL II SCOUR ANALYSIS FOR BRIDGE 13 (IRA-VT01330013) ON STATE ROUTE 133, CROSSING AN IRA BROOK TRIBUTARY, IRA, VERMONT
}

\author{
By Erick M. Boehmler and Michael A. Ivanoff
}

\section{INTRODUCTION AND SUMMARY OF RESULTS}

This report provides the results of a detailed Level II analysis of scour potential at structure IRA-VT01330013 on State Route 133 crossing an Ira Brook Tributary, Ira, Vermont (figures 1-8). A Level II study is a basic engineering analysis of the site, including a quantitative analysis of stream stability and scour (U.S. Department of Transportation, 1993). Results of a Level I scour investigation also are included in Appendix E of this report. A Level I investigation provides a qualitative geomorphic characterization of the study site. Information on the bridge, gleaned from Vermont Agency of Transportation (VTAOT) files, was compiled prior to conducting Level I and Level II analyses and is found in Appendix D.

The site is in the Taconic section of the New England physiographic province in westcentral Vermont. The $2.88-\mathrm{mi}^{2}$ drainage area is in a predominantly rural and forested basin. In the vicinity of the study site, the surface cover is pasture while the immediate banks have dense tree cover.

In the study area, this Ira Brook Tributary has an incised, sinuous channel with a slope of approximately $0.02 \mathrm{ft} / \mathrm{ft}$, an average channel top width of $40 \mathrm{ft}$ and an average channel depth of $7 \mathrm{ft}$. The predominant channel bed material is cobble with a median grain size $\left(\mathrm{D}_{50}\right)$ of $71.9 \mathrm{~mm}(0.236 \mathrm{ft})$. The geomorphic assessment at the time of the Level I and Level II site visit on June 14, 1995, indicated that the reach was stable.

The State Route 133 crossing of this Ira Brook Tributary is a 28-ft-long, two-lane bridge consisting of one 26-foot concrete span (Vermont Agency of Transportation, written communication, March 13, 1995). The bridge is supported by vertical, concrete abutments with wingwalls. The channel is skewed approximately 20 degrees to the opening while the opening-skew-to-roadway is 5 degrees.

A scour hole, approximately $0.5 \mathrm{ft}$ deeper than the mean thalweg depth, was observed at the downstream end of the left abutment wall during the Level I assessment. The scour protection measures at the site were type- 1 stone fill (less than 12 inches diameter) on the upstream left bank and upstream left wingwall and type-2 stone fill (less than 36 inches 
diameter) on the upstream right bank, upstream right wingwall, the downstream wingwalls and downstream banks. Additional details describing conditions at the site are included in the Level II Summary and Appendices D and E.

Scour depths and rock rip-rap sizes were computed using the general guidelines described in Hydraulic Engineering Circular 18 (Richardson and others, 1995). Total scour at a highway crossing is comprised of three components: 1) long-term streambed degradation; 2) contraction scour (due to accelerated flow caused by a reduction in flow area at a bridge) and; 3) local scour (caused by accelerated flow around piers and abutments). Total scour is the sum of the three components. Equations are available to compute depths for contraction and local scour and a summary of the results of these computations follows.

There was no computed contraction scour for any of the modelled flows. Abutment scour ranged from 3.6 to $4.7 \mathrm{ft}$. The worst-case abutment scour occurred at the 500-year discharge. Additional information on scour depths and depths to armoring are included in the section titled "Scour Results". Scoured-streambed elevations, based on the calculated scour depths, are presented in tables 1 and 2. A cross-section of the scour computed at the bridge is presented in figure 8 . Scour depths were calculated assuming an infinite depth of erosive material and a homogeneous particle-size distribution.

It is generally accepted that the Froehlich equation (abutment scour) gives "excessively conservative estimates of scour depths" (Richardson and others, 1995, p. 47). Usually, computed scour depths are evaluated in combination with other information including (but not limited to) historical performance during flood events, the geomorphic stability assessment, existing scour protection measures, and the results of the hydraulic analyses. Therefore, scour depths adopted by VTAOT may differ from the computed values documented herein. 


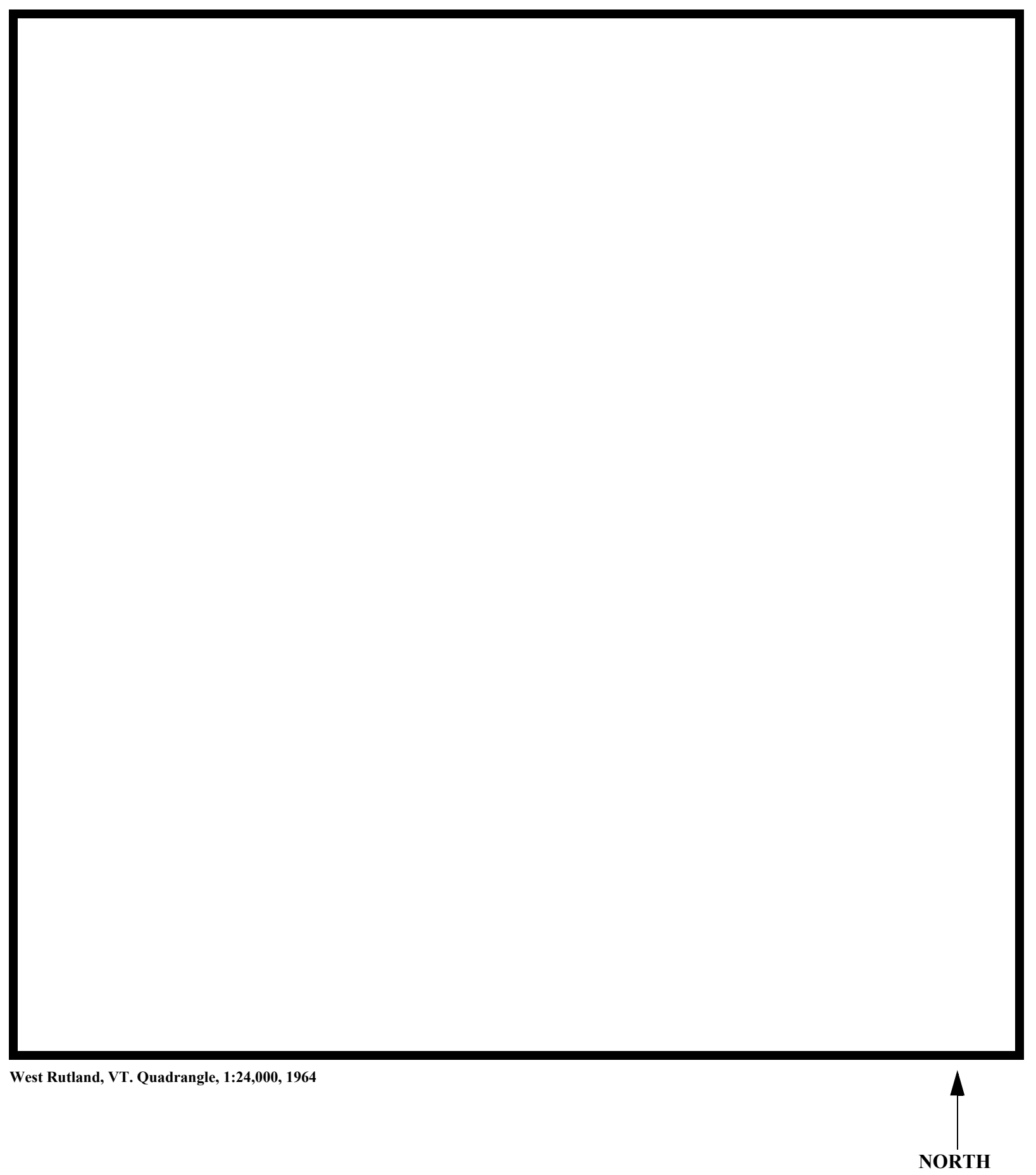

Figure 1. Location of study area on USGS 1:24,000 scale map. 
Figure 2. Location of study area on Vermont Agency of Transportation town highway map. 

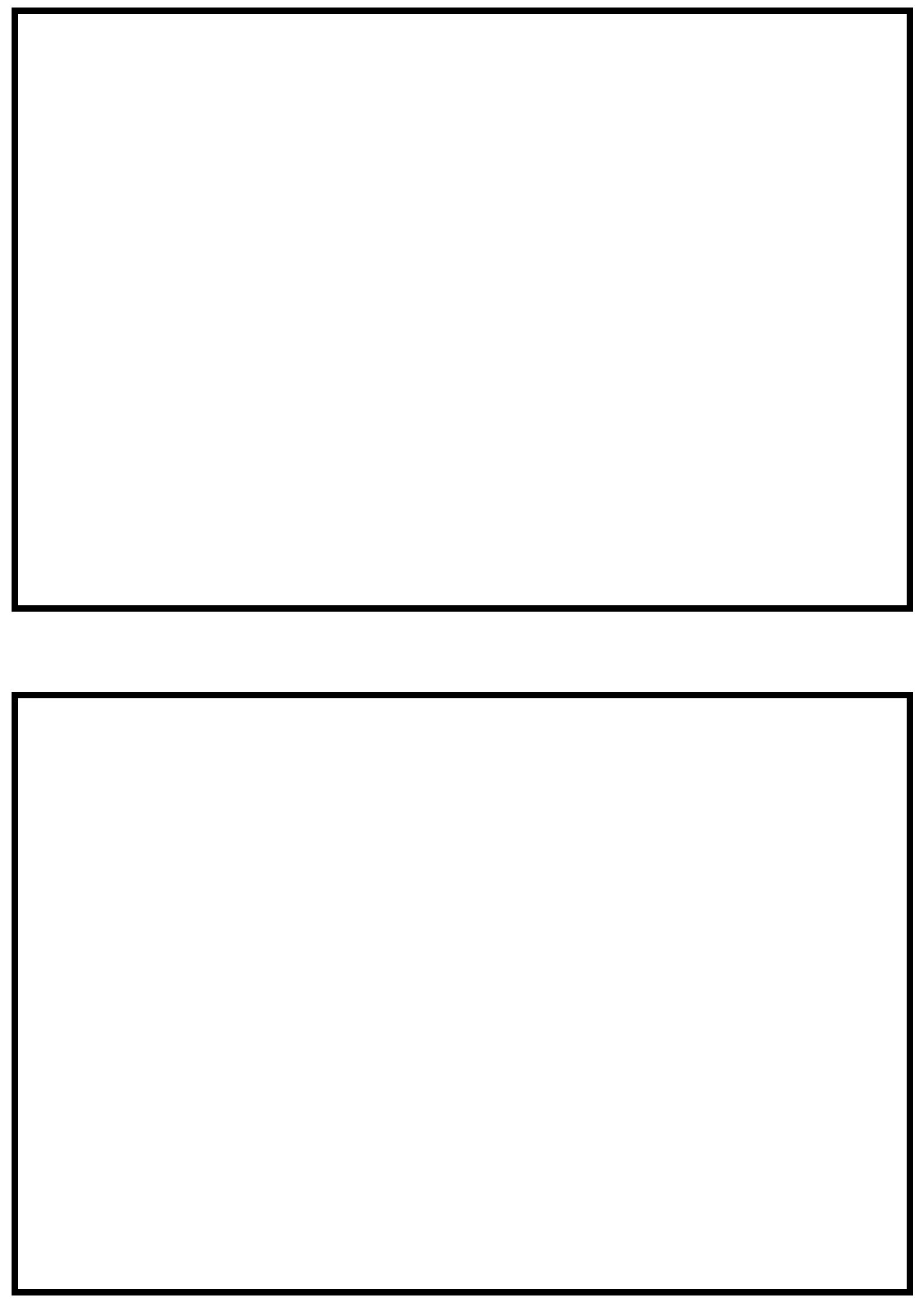

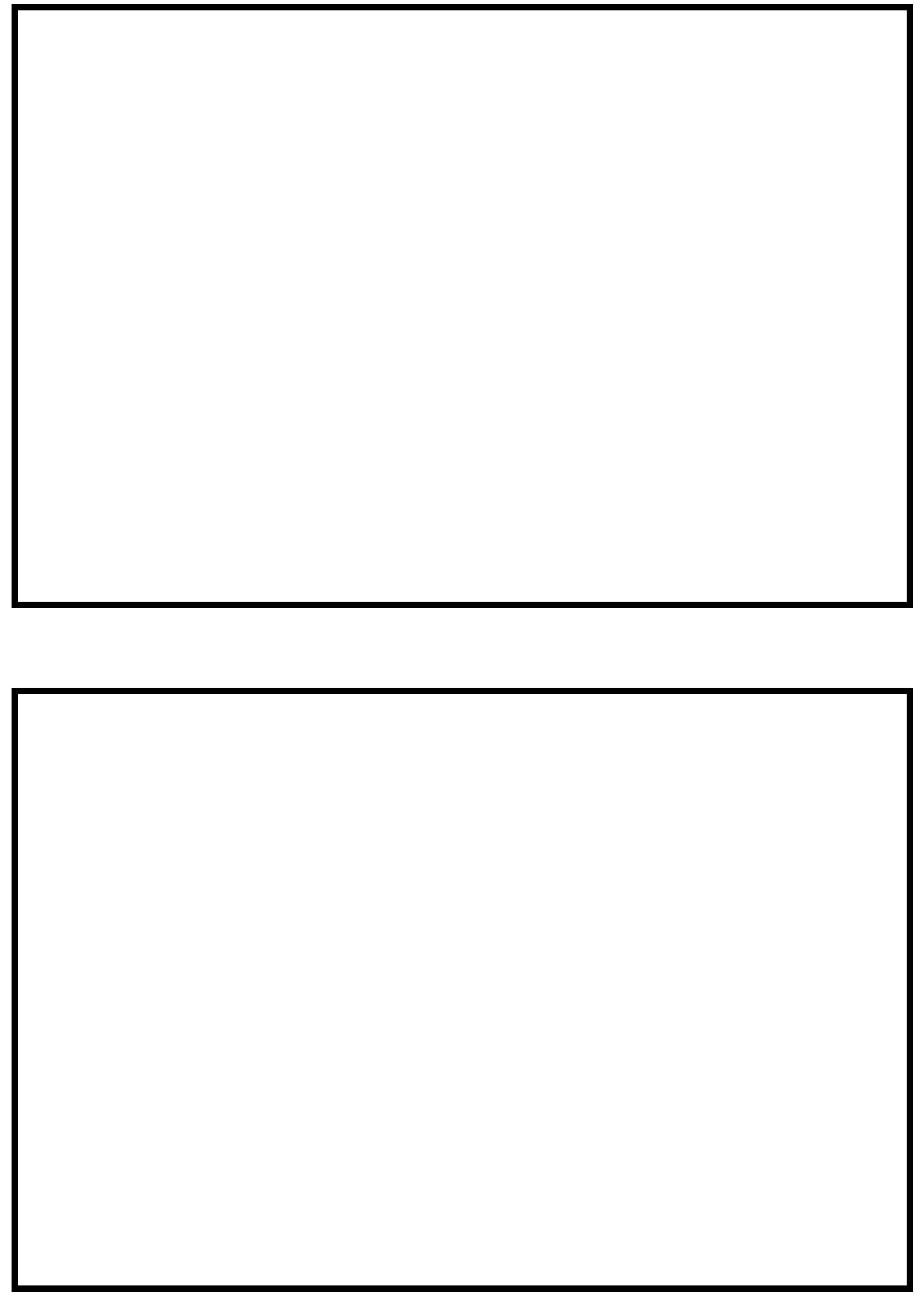


\section{LEVEL II SUMMARY}

\begin{tabular}{llllll} 
Structure Number & IRA-VT01330013 & \multirow{2}{*}{ Stream } & \multicolumn{3}{c}{ Ira Brook Tributary } \\
& Road & VT 133 & District & 3
\end{tabular}

\section{Description of Bridge}

Bridge length $\stackrel{28}{2} \boldsymbol{f t}$ Bridge width $\stackrel{31.2}{f t}$ Max span length $\stackrel{26}{ } \boldsymbol{f t}$ Alignment of bridge to road (on curve or straight)

Abutment type Vertical, concrete

Stone fill on abutment?

$$
\text { No }
$$

\section{Embankment type} Straight

on the remaining wingwalls and banks.

Abutments and wingwalls are concrete. There is a scour hole approximately $0 . \dot{\mathrm{ft}}$ deep at the downstream end of the left abutment.

\section{$\mathrm{Y}$}

Is bridge skewed to flood flow according to Y r survey?

Angle

There is a mild channel bend in the reach. The scour hole has developed in the location where the bend impacts the downstream end of the left abutment.

Debris accumulation on bridge at time of Level I or Level II site visit:

Date of insmortion $6 / 14 / 95$

Level I

$$
6 / 14 / 95
$$

Level II

Moderate. Trees leaning over the channel upstream and many dead trees on the banks were noted.

Potential for debris

None noted on 6/14/95.

Dosrriho anv fonturos noar ar at tho hridoo that mav affort flow, (includo ohsorvation dato) 


\section{Description of the Geomorphic Setting}

General topography The channel is located in a moderate relief valley setting with an irregular flood plain and no valley walls.

Geomorphic conditions at bridge site: downstream (DS), upstream (US)

Date of inspection $\quad 6 / 14 / 95$

DS left: $\quad$ Steep channel bank to flood plain.

DS right: $\quad$ Steep channel bank to flood plain

US left: $\quad$ Moderately sloping channel bank to flood plain.

US right: $\quad$ Steep channel bank to flood plain.

\section{Description of the Channel}

\begin{tabular}{|c|c|c|c|c|}
\hline & 40 & & 7 & \\
\hline Average top width & Cobbles & Average depth & Cobbles & $f t$ \\
\hline
\end{tabular}

Predominant bed material Bank material Perennial but flashy

and straight with non-alluvial channel boundaries.

$6 / 14 / 95$

Vegetative co 1 Trees.

DS left: $\quad$ Trees

DS right: $\quad$ Trees

US left: $\quad$ Trees.

US right: $\quad \underline{\mathrm{Y}}$

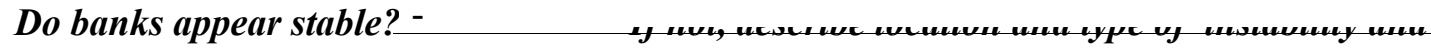

date of observatton.

None evident on

$6 / 14 / 95$.

Describe any obstructions in channel and date of observation. 


\title{
Hydrology
}

Drainage area $\stackrel{2.88}{\mathbf{m i}} \mathbf{m}^{2}$

Percentage of drainage area in physiographic provinces: (approximate)

Physiographic province/section New England / Taconic
Percent of drainage area 100

\begin{abstract}
Is drainage area considered rural or urban?
Rural urbanization:

Describe any significant
\end{abstract}

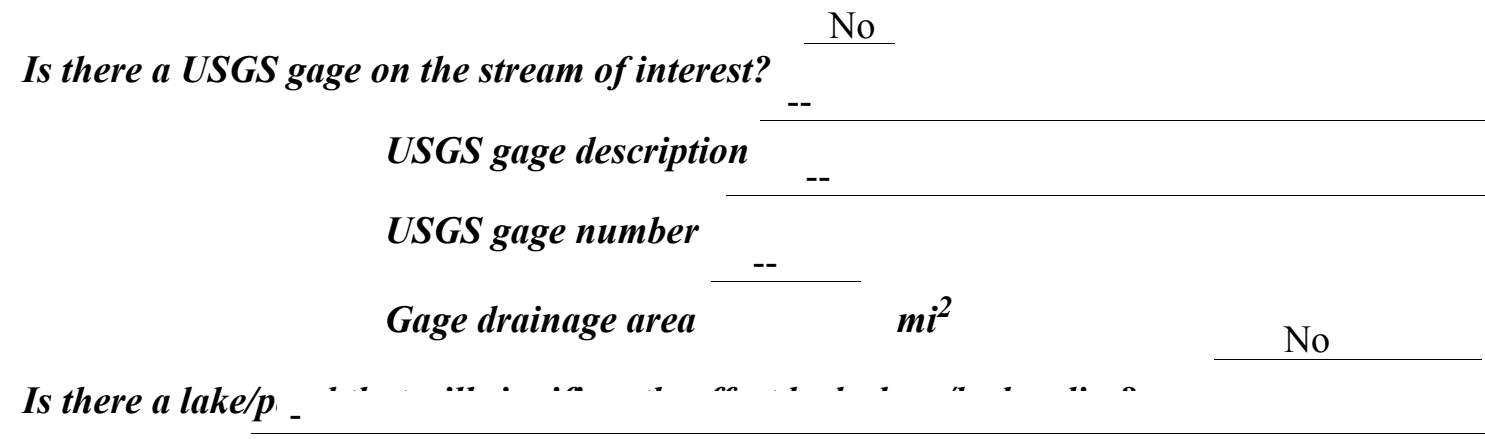

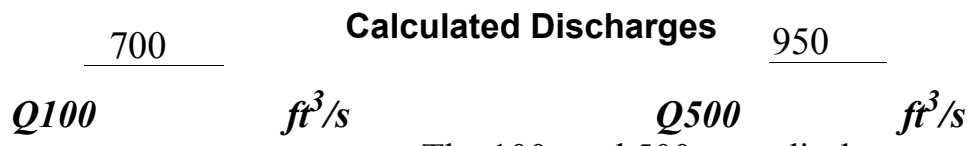

The 100- and 500-year discharges are based on

discharge frequency curves computed by use of several empirical equations (Benson, 1962;

FHWA, 1983; Johnson and Laraway, unpublished draft, 1972; Johnson and Tasker, 1974; Potter, $1957 \mathrm{a} \& \mathrm{~b}$; and Talbot, 1887) and values available from the VTAOT database (written communication, May, 1995). The 100- and 500-year discharges selected and noted above for this hydraulic analysis are from the VTAOT database due to the central tendency of the VTAOT curve with the others. 


\section{Description of the Water-Surface Profile Model (WSPRO) Analysis}

Datum for WSPRO analysis (USGS survey, sea level, VTAOT plans)

USGS survey

Datum tie between USGS survey and VTAOT plans

None

Description of reference marks used to determine USGS datum. $\quad$ RM1 is the center point

of a chiseled "X" on top of the concrete left abutment, downstream end (elev. $500.52 \mathrm{ft}$, arbitrary

survey datum). RM2 is the center point of a chiseled " $\mathrm{X}$ " on top of concrete right abutment,

upstream end (elev. $501.20 \mathrm{ft}$, arbitrary survey datum).

\section{Cross-Sections Used in WSPRO Analysis}

\begin{tabular}{|c|c|c|c|}
\hline${ }^{1}$ Cross-section & $\begin{array}{c}\text { Section } \\
\text { Reference } \\
\text { Distance } \\
\text { (SRD) in feet }\end{array}$ & $\begin{array}{c}{ }^{2} \text { Cross-section } \\
\text { development }\end{array}$ & Comments \\
\hline EXITX & -22 & 1 & Exit section \\
\hline FULLV & 0 & 2 & $\begin{array}{l}\text { Downstream Full-valley } \\
\text { section (Templated from } \\
\text { EXITX) }\end{array}$ \\
\hline BRIDG & 0 & 1 & Bridge section \\
\hline RDWAY & 13 & 1 & Road Grade section \\
\hline APPRO & 48 & 2 & $\begin{array}{l}\text { Modelled Approach sec- } \\
\text { tion (Templated from } \\
\text { APTEM) }\end{array}$ \\
\hline APTEM & 52 & 1 & $\begin{array}{l}\text { Approach section as sur- } \\
\text { veyed (Used as a tem- } \\
\text { plate) }\end{array}$ \\
\hline
\end{tabular}

${ }^{1}$ For location of cross-sections see plan-view sketch included with Level I field form, Appendix E.

For more detail on how cross-sections were developed see WSPRO input file. 


\section{Data and Assumptions Used in WSPRO Model}

Hydraulic analyses of the reach were done by use of the Federal Highway Administration's WSPRO step-backwater computer program (Shearman and others, 1986, and Shearman, 1990). The analyses reported herein reflect conditions existing at the site at the time of the study. Furthermore, in the development of the model it was necessary to assume no accumulation of debris or ice at the site. Results of the hydraulic model are presented in the Bridge Hydraulic Summary, Appendix B, and figure 7.

Channel roughness factors (Manning's " $n$ ") used in the hydraulic model were estimated using field inspections at each cross section following the general guidelines described by Arcement and Schneider (1989). Final adjustments to the values were made during the modelling of the reach. Channel " $n$ " values for the reach ranged from 0.045 to 0.065 , and overbank " $n$ " values ranged from 0.070 to 0.080 .

This tributary enters Ira Brook approximately 900 feet downstream. Because of the similar basin characteristics of this tributary and Ira Brook, peak flows could occur simultaneously. If peaks were concurrent, backwater from Ira Brook may influence the hydraulics at this site. However, for this hydraulic analysis, normal depth (no backwater) at the exit section (EXITX) was assumed as the starting water surface. This depth was computed by use of the slope-conveyance method outlined in the user's manual for WSPRO (Shearman, 1990). The slope used was $0.0220 \mathrm{ft} / \mathrm{ft}$ which was estimated from the topographic map (U.S. Geological Survey, 1964).

The surveyed approach section (APTEM) was moved along the approach channel slope $(0.0245 \mathrm{ft} / \mathrm{ft})$ to establish the modelled approach section (APPRO), one bridge length upstream of the upstream face as recommended by Shearman and others (1986). This method also provides a consistent approach for determining scour variables. 


\section{Bridge Hydraulics Summary}

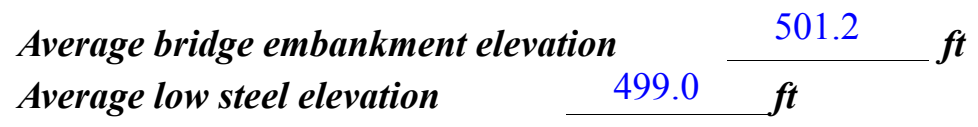

$$
\text { 100-year discharge } \quad 700 \quad \mathrm{ft}^{3} / \mathrm{s}
$$

Water-surface elevation in bridge opening $\quad 495.1 \quad f t$

Road overtopping? ___ No Discharge over road ___-- $\mathrm{ft}^{3} / \mathrm{s}$

\begin{tabular}{llll} 
Area of flow in bridge opening & $94.9 \quad \boldsymbol{f t}^{2}$ \\
\cline { 2 - 3 } Average velocity in bridge opening & 7.4 & $\mathbf{f t} / \mathbf{s}$
\end{tabular}

Maximum WSPRO tube velocity at bridge $\quad \begin{array}{lll}9.5 & \mathrm{t} / \mathrm{s}\end{array}$

Water-surface elevation at Approach section with bridge

Water-surface elevation at Approach section without bridge

495.5

Amount of backwater caused by bridge

$0 \quad$ it

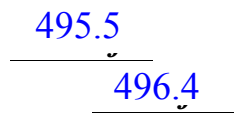

500-year discharge $\quad 950 \quad \mathrm{ft}^{3} / \mathrm{s}$

Water-surface elevation in bridge opening

$495.5 \boldsymbol{f t}$

Road overtopping? ___ No Discharge over road __ -- $\quad 3 / \mathrm{s}$

Area of flow in bridge opening $\quad 104 \quad \mathrm{ft}^{2}$

Average velocity in bridge opening $\quad 9.1 \mathrm{ft} / \mathrm{s}$

Maximum WSPRO tube velocity at bridge 11.6 , 's

Water-surface elevation at Approach section with bridge 496.3

Water-surface elevation at Approach section without bridge $\quad 497.2$

Amount of backwater caused by bridge 0 .

Incipient overtopping discharge ___ -- $\mathrm{ft}^{3} / \mathrm{s}$

Water-surface elevation in bridge opening $\quad--\quad$ it

Area of flow in bridge opening _ -- $\mathrm{ft}^{2}$

Average velocity in bridge opening ___ $\quad--\quad f t / s$

Maximum WSPRO tube velocity at bridge _ -- $\mathrm{ft} / \mathrm{s}$

Water-surface elevation at Approach section with bridge

Water-surface elevation at Approach section without bridge

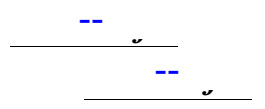
Amount of backwater caused by bridge _ 


\section{Scour Analysis Summary}

\section{Special Conditions or Assumptions Made in Scour Analysis}

Scour depths were computed using the general guidelines described in Hydraulic Engineering Circular 18 (Richardson and others, 1995). Scour depths were calculated assuming an infinite depth of erosive material and a homogeneous particle-size distribution. The results of the scour analysis are presented in tables 1 and 2 and a graph of the scour depths is presented in figure 8.

Contraction scour was computed by use of the live-bed contraction scour equation (Richardson and others, 1995, p. 30, equation 17). For contraction scour computations, the average depth in the contracted section (AREA/TOPWIDTH) is subtracted from the depth of flow computed by the scour equation (Y2) to determine the actual amount of scour. For this case, the computations resulted in no contraction scour.

Abutment scour was computed by use of the Froehlich equation (Richardson and others, 1995, p. 48, equation 28). Variables for the Froehlich equation include the Froude number of the flow approaching the embankments, the length of the embankment blocking flow, and the depth of flow approaching the embankment less any roadway overtopping. 


\section{Scour Results}

100-yr discharge 500-yr discharge

Incipient

Contraction scour:

(Scour depths in feet)

Main channel

Local scour:

4.7

overtopping

discharge
(1)
(n)

Live-bed scour

Clear-water scour

Depth to armoring

Left overbank

Right overbank

Abutment scour

Left abutment

3.6

0.0

$--$

$1.0^{-}$

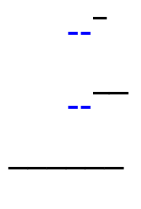

$3.6-$

Right abutment

Pier scour
Pier 1
Pier 2
Pier 3

Abutments:

Left abutment

Right abutment

Piers:

Pier 1

Pier 2

\section{Riprap Sizing}

4.7-
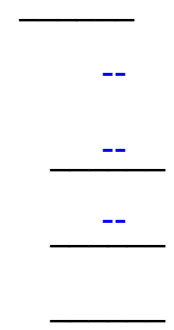

$--$

--

--
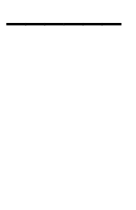


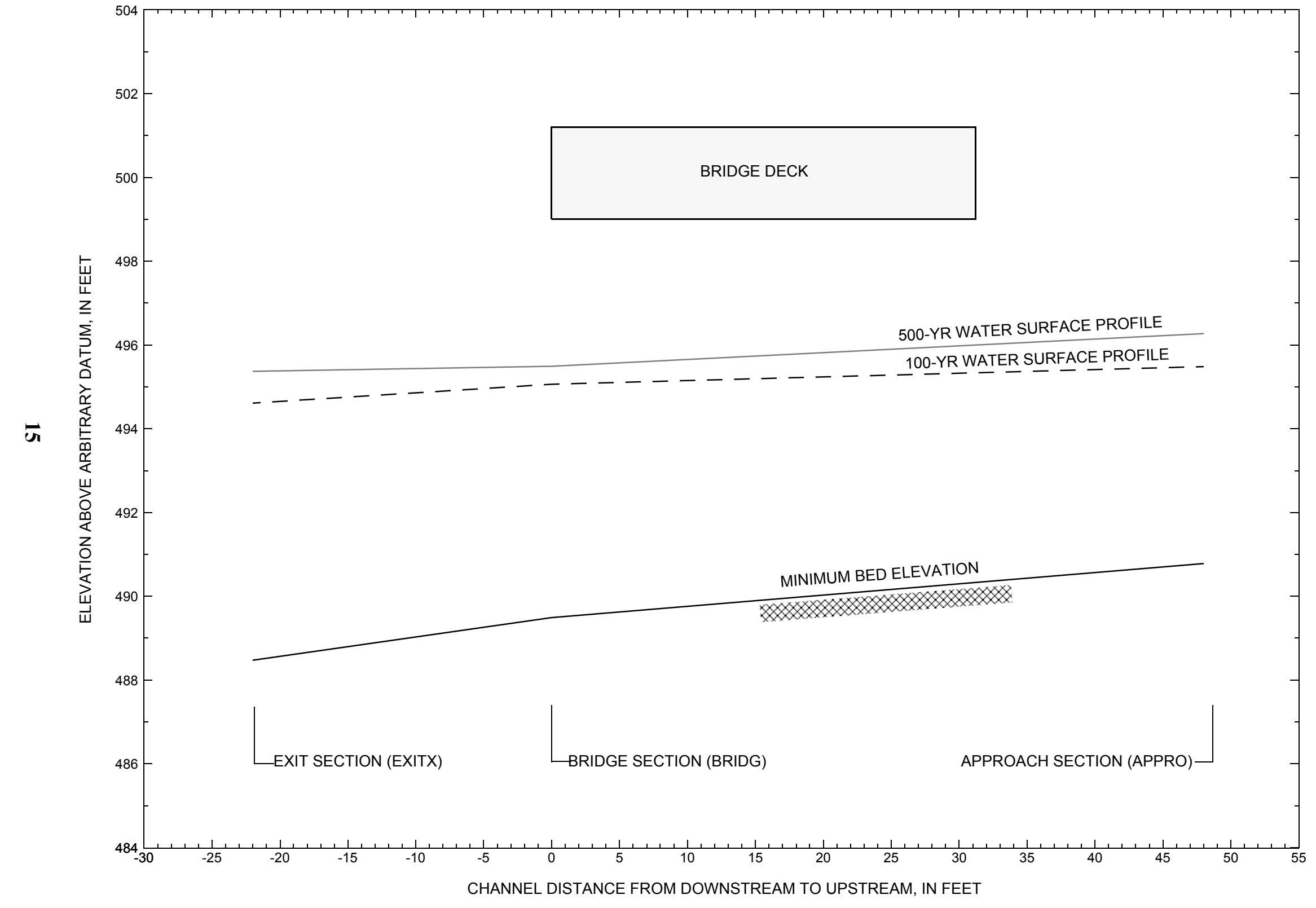

Figure 7. Water-surface profiles for the 100- and 500-yr discharges at structure IRA-VT01330013 on State Route 133, crossing an Ira Brook Tributary, Ira, Vermont. 


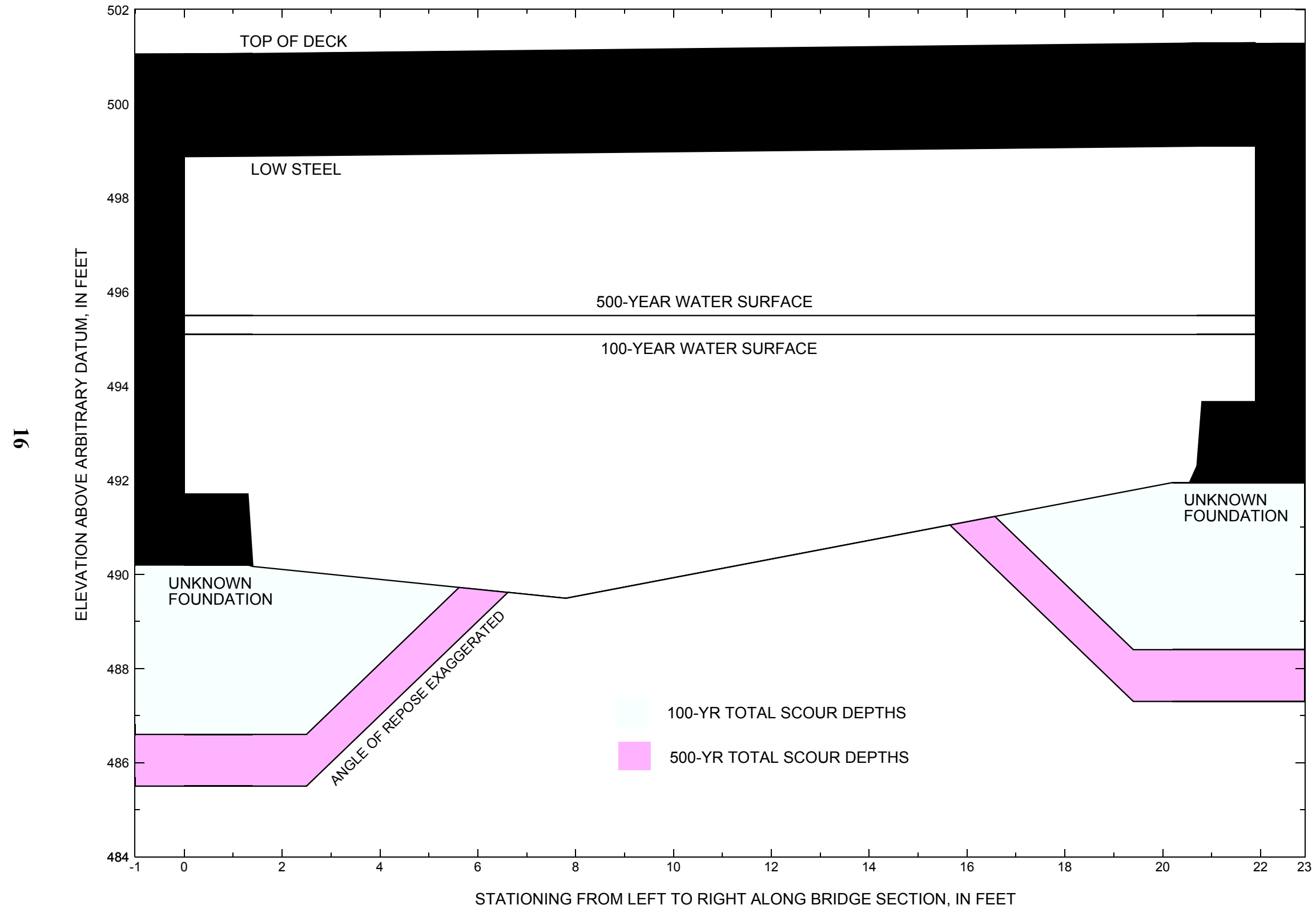

Figure 8. Scour elevations for the 100-yr and 500-yr discharges at structure IRA-VT01330013 on State Route 133, crossing an Ira Brook Tributary, Ira, Vermont. 
Table 1. Remaining footing/pile depth at abutments for the 100-year discharge at structure IRA-VT01330013 on State Route 133, crossing an Ira Brook Tributary, Ira, Vermont.

[VTAOT, Vermont Agency of Transportation; --,no data]

\begin{tabular}{|c|c|c|c|c|c|c|c|c|c|c|c|}
\hline Description & Station $^{1}$ & $\begin{array}{l}\text { VTAOT } \\
\text { minimum } \\
\text { low-chord } \\
\text { elevation } \\
\text { (feet) }\end{array}$ & $\begin{array}{c}\text { Surveyed } \\
\text { minimum } \\
\text { low-chord } \\
\text { elevation }{ }^{2} \\
\text { (feet) }\end{array}$ & $\begin{array}{c}\text { Bottom of } \\
\text { footing } \\
\text { elevation } \\
\text { (feet) }\end{array}$ & $\begin{array}{c}\text { Channel } \\
\text { elevation at } \\
\text { abutment/ } \\
\text { pier }^{2} \\
\text { (feet) }\end{array}$ & $\begin{array}{l}\text { Contraction } \\
\text { scour depth } \\
\text { (feet) }\end{array}$ & $\begin{array}{l}\text { Abutment } \\
\text { scour } \\
\text { depth } \\
\text { (feet) }\end{array}$ & $\begin{array}{l}\text { Pier } \\
\text { scour } \\
\text { depth } \\
\text { (feet) }\end{array}$ & $\begin{array}{l}\text { Depth of } \\
\text { total scour } \\
\text { (feet) }\end{array}$ & $\begin{array}{c}\text { Elevation of } \\
\text { scour }^{2} \\
\text { (feet) }\end{array}$ & $\begin{array}{c}\text { Remaining } \\
\text { footing/pile } \\
\text { depth } \\
\text { (feet) }\end{array}$ \\
\hline \multicolumn{12}{|c|}{100 -yr. discharge is 700 cubic-feet per second } \\
\hline Left abutment & 0.0 & -- & 498.9 & -- & 490.2 & 0.0 & 3.6 & -- & 3.6 & 486.6 & -- \\
\hline Right abutment & 21.9 & -- & 499.1 & -- & 492.0 & 0.0 & 3.6 & -- & 3.6 & 488.4 & -- \\
\hline
\end{tabular}

1.Measured along the face of the most constricting side of the bridge.

2.Arbitrary datum for this study.

Table 2. Remaining footing/pile depth at abutments for the 500-year discharge at structure IRA-VT01330013 on State Route 133, crossing an Ira Brook Tributary, Ira, Vermont.

[VTAOT, Vermont Agency of Transportation; --, no data]

\begin{tabular}{|c|c|c|c|c|c|c|c|c|c|c|c|}
\hline Description & Station $^{1}$ & $\begin{array}{l}\text { VTAOT } \\
\text { minimum } \\
\text { low-chord } \\
\text { elevation } \\
\text { (feet) }\end{array}$ & $\begin{array}{c}\text { Surveyed } \\
\text { minimum } \\
\text { low-chord } \\
\text { elevation } \\
\text { (feet) }\end{array}$ & $\begin{array}{c}\text { Bottom of } \\
\text { footing } \\
\text { elevation } \\
\text { (feet) }\end{array}$ & $\begin{array}{c}\text { Channel } \\
\text { elevation at } \\
\text { abutment/ } \\
\text { pier }^{2} \\
\text { (feet) }\end{array}$ & $\begin{array}{l}\text { Contraction } \\
\text { scour depth } \\
\text { (feet) }\end{array}$ & $\begin{array}{c}\text { Abutment } \\
\text { scour } \\
\text { depth } \\
\text { (feet) }\end{array}$ & $\begin{array}{l}\text { Pier } \\
\text { scour } \\
\text { depth } \\
\text { (feet) }\end{array}$ & $\begin{array}{l}\text { Depth of } \\
\text { total scour } \\
\text { (feet) }\end{array}$ & $\begin{array}{c}\text { Elevation of } \\
\text { scour }^{2} \\
\text { (feet) }\end{array}$ & $\begin{array}{c}\text { Remaining } \\
\text { footing/pile } \\
\text { depth } \\
\text { (feet) }\end{array}$ \\
\hline \multicolumn{12}{|c|}{500 -yr. discharge is 950 cubic-feet per second } \\
\hline Left abutment & 0.0 & -- & 498.9 & -- & 490.2 & 0.0 & 4.7 & -- & 4.7 & 485.5 & -- \\
\hline Right abutment & 21.9 & -- & 499.1 & -- & 492.0 & 0.0 & 4.7 & -- & 4.7 & 487.3 & -- \\
\hline
\end{tabular}

1.Measured along the face of the most constricting side of the bridge.

2.Arbitrary datum for this study. 


\section{SELECTED REFERENCES}

Arcement, G.J., Jr., and Schneider, V.R., 1989, Guide for selecting Manning's roughness coefficients for natural channels and flood plains: U.S. Geological Survey Water-Supply Paper 2339, 38 p.

Barnes, H.H., Jr., 1967, Roughness characteristics of natural channels: U.S. Geological Survey Water-Supply Paper 1849,213 p.

Benson, M. A., 1962, Factors Influencing the Occurrence of Floods in a Humid Region of Diverse Terrain: U.S. Geological Survey WaterSupply Paper 1580-B, 64 p.

Brown, S.A. and Clyde, E.S., 1989, Design of riprap revetment: Federal Highway Administration Hydraulic Engineering Circular No. 11, Publication FHWA-IP-89-016, 156 p.

Federal Highway Administration, 1983, Runoff estimates for small watersheds and development of sound design: Federal Highway Administration Report FHWA-RD-77-158

Froehlich, D.C., 1989, Local scour at bridge abutments in Ports, M.A., ed., Hydraulic Engineering--Proceedings of the 1989 National Conference on Hydraulic Engineering: New York, American Society of Civil Engineers, p. 13-18.

Hayes, D.C.,1993, Site selection and collection of bridge-scour data in Delaware, Maryland, and Virginia: U.S. Geological Survey WaterResources Investigation Report 93-4017, 23 p.

Interagency Advisory Committee on Water Data, 1982, Guidelines for determining flood flow frequency: U.S. Geological Survey, Bulletin 17B of the Hydrology Subcommittee, 190 p.

Johnson, C.G. and Tasker, G.D.,1974, Progress report on flood magnitude and frequency of Vermont streams: U.S. Geological Survey OpenFile Report 74-130, 37 p.

Lagasse, P.F., Schall, J.D., Johnson, F., Richardson, E.V., Chang, F., 1995, Stream Stability at Highway Structures: Federal Highway Administration Hydraulic Engineering Circular No. 20, Publication FHWA-IP-90-014, 144 p.

Laursen, E.M., 1960, Scour at bridge crossings: Journal of the Hydraulics Division, American Society of Civil Engineers, v. 86, no. HY2, p. 39-53.

Potter, W. D., 1957a, Peak rates of runoff in the Adirondack, White Mountains, and Maine woods area, Bureau of Public Roads

Potter, W. D., 1957b, Peak rates of runoff in the New England Hill and Lowland area, Bureau of Public Roads

Richardson, E.V. and Davis, S.R., 1995, Evaluating scour at bridges: Federal Highway Administration Hydraulic Engineering Circular No. 18, Publication FHWA-IP-90-017, 204 p.

Richardson, E.V., Simons, D.B., and Julien, P.Y., 1990, Highways in the river environment: Federal Highway Administration Publication FHWA-HI-90-016.

Ritter, D.F., 1984, Process Geomorphology: W.C. Brown Co., Debuque, Iowa, 603 p.

Shearman, J.O., 1990, User's manual for WSPRO--a computer model for water surface profile computations: Federal Highway Administration Publication FHWA-IP-89-027, 187 p.

Shearman, J.O., Kirby, W.H., Schneider, V.R., and Flippo, H.N., 1986, Bridge waterways analysis model; research report: Federal Highway Administration Publication FHWA-RD-86-108, 112 p.

Talbot, A.N., 1887, The determination of water-way for bridges and culverts.

U.S. Department of Transportation, 1993, Stream stability and scour at highway bridges, Participant Workbook: Federal Highway Administration Publication FHWA HI-91-011.

U.S. Geological Survey, 1964, West Rutland, Vermont 7.5 Minute Series quadrangle map: U.S. Geological Survey Topographic Maps, Aerial photographs, 1962, Contour interval, 20 feet, Scale 1:24,000. 


\section{APPENDIX A: \\ WSPRO INPUT FILE}




\section{WSPRO INPUT FILE}

GR

GR

GR

GR

*

$\mathrm{N}$

SA

*

XS

*

*

BR

GR

GR

GR

*

CD

$\mathrm{N}$

*

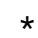

$\mathrm{XR}$

GR

BP

*

*

$\mathrm{XT}$

GR

GR

GR

*

AS

GT

BP

$\mathrm{N}$

SA

*

HP 1 BRIDG 495.061495 .06

HP 2 BRIDG 495.06 * *700

HP 1 APPRO 495.481495 .48

HP 2 APPRO 495.48 * * 700

HP 1 BRIDG 495.49 1495.49

HP 2 BRIDG 495.49 * * 950

HP 1 APPRO $496.27 \quad 1 \quad 496.27$

HP 2 APPRO 496.27 * * 950

APTEM 52

$-125.4,498.34$

$7.0,491.30$
$-35.0,498.09$

$7.1,489.18$

$31.6,495.10$

$101.7,496.28$

$-12.8,495.96$

$10.8,488.47$

$43.0,496.12$

0.080

31.6

0.045

XSSKEW

5.0

$0.0,491.72$

$10.7,490.07$

$21.9,493.67$

$1.3,491.71$

$1.4,490.17$

$20.2,491.95$

$21.9,499.11$

$20.7,492.28$

$0.0,498.88$
$-2.1,493.92$

$14.0,489.17$

$61.4,495.96$

EMB

$-13.2,498.52$

$-7.2,498.43$

$11.3,490.88$

$16.6,491.34$

$21.8,494.81$

\section{*}




\section{APPENDIX B: \\ WSPRO OUTPUT FILE}


WSPRO OUTPUT FILE

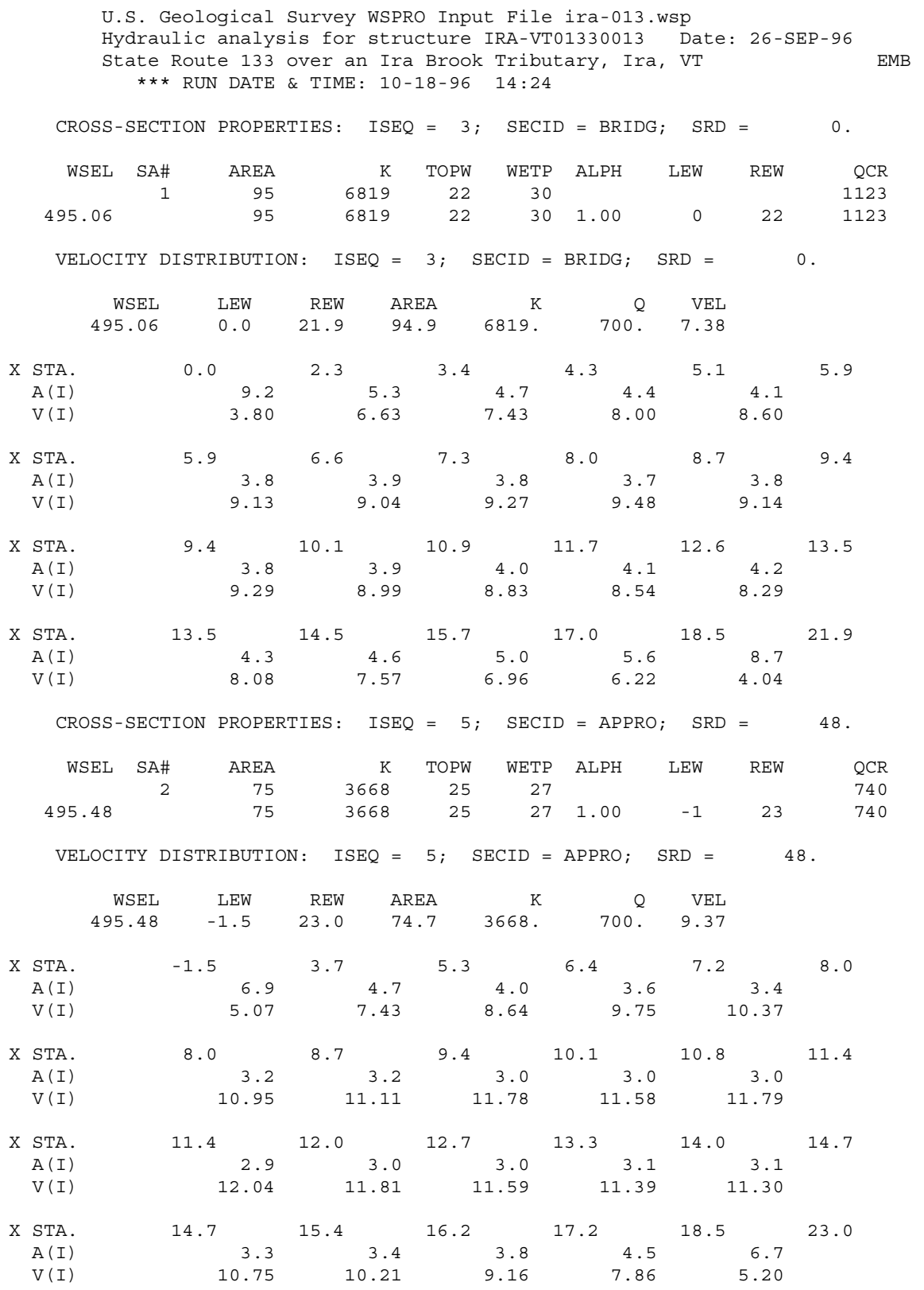


WSPRO OUTPUT FILE (continued)

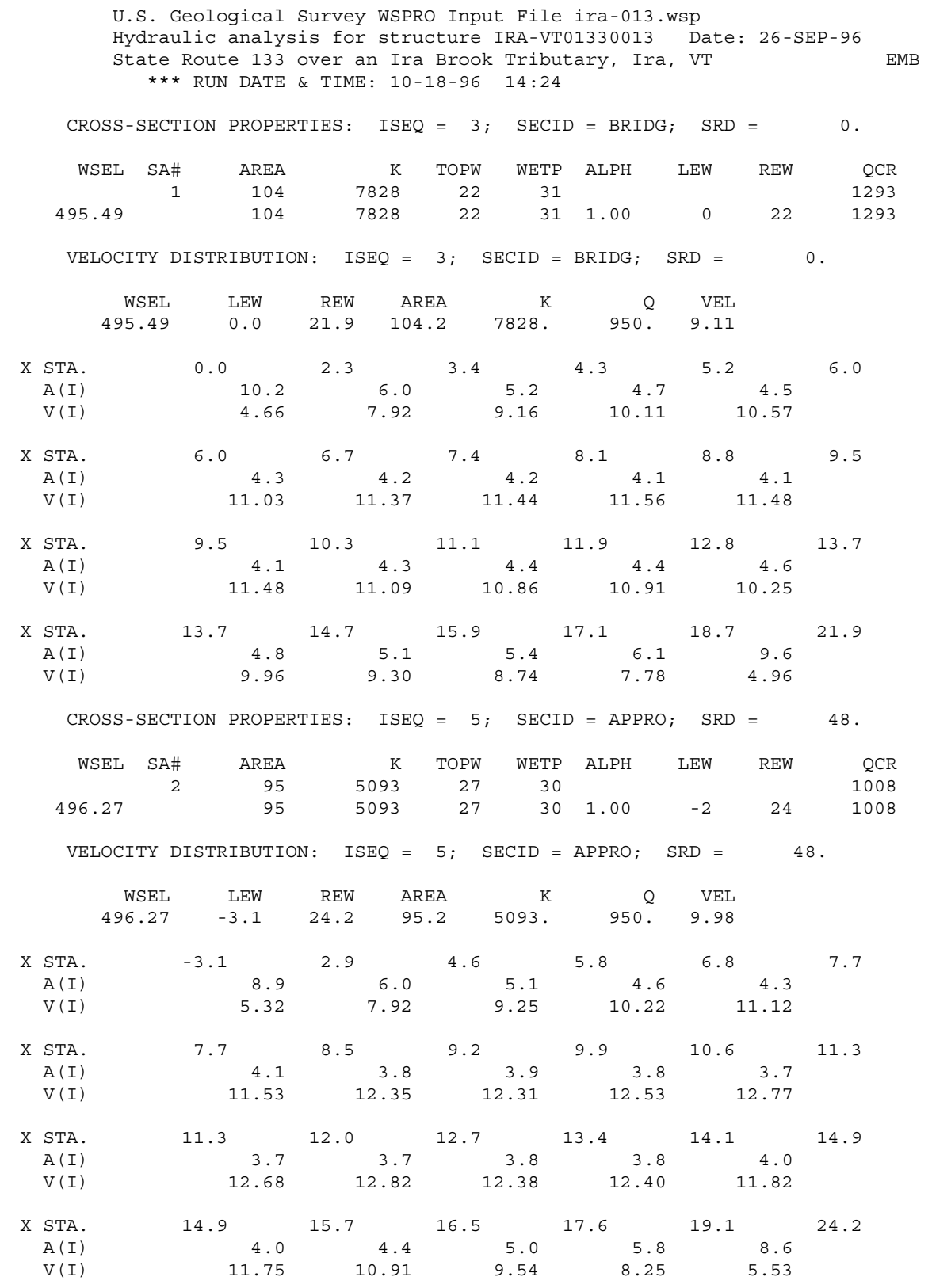


WSPRO OUTPUT FILE (continued)

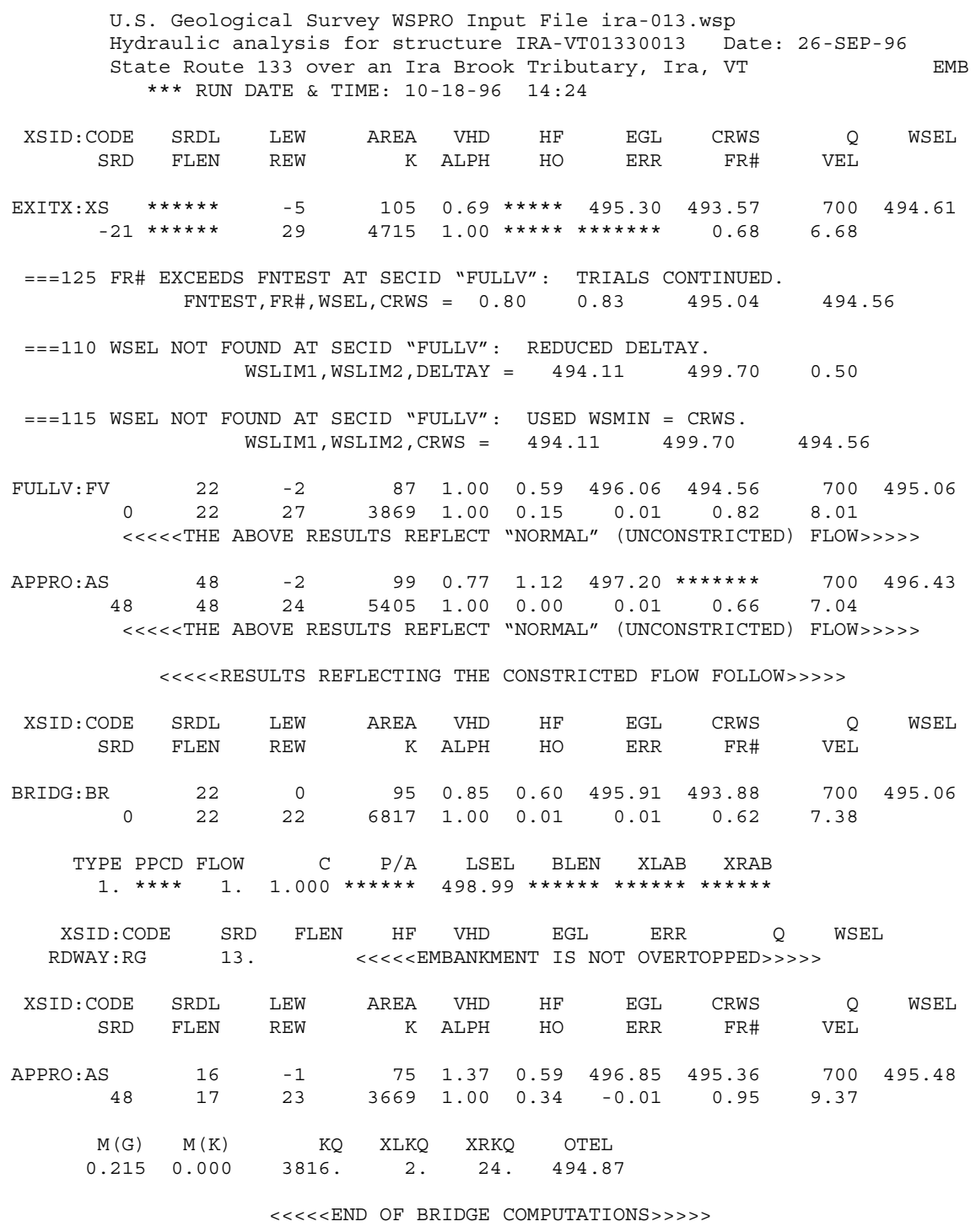

FIRST USER DEFINED TABLE.

\begin{tabular}{|c|c|c|c|c|c|c|c|c|}
\hline XSID : CODE & SRD & LEW & REW & $\mathrm{Q}$ & K & AREA & VEL & WSEL \\
\hline EXITX:XS & -22 & -6 & 29. & 700. & 4715 . & 105. & 6.68 & 494.61 \\
\hline FULLV : FV & 0 . & -3 . & 27. & 700. & 3869. & 87. & 8.01 & 495.06 \\
\hline BRIDG : BR & 0 . & 0 . & 22 . & 700. & 6817. & 95. & 7.38 & 495.06 \\
\hline RDWAY : RG & \multicolumn{3}{|c|}{$13 . * * \star * * * \star * \star * * * \star * \star *$} & \multicolumn{3}{|c|}{ 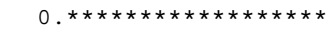 } & \multicolumn{2}{|c|}{$1.00 * * * * * * * *$} \\
\hline APPRO: AS & 48 & -2 & 23. & 700. & 3669. & 75. & 9.37 & 495.48 \\
\hline XSID : CODE & XLKQ & $\mathrm{XRKQ}$ & & & & & & \\
\hline APPRO : AS & 2. & 24. & 3816 & & & & & \\
\hline
\end{tabular}

SECOND USER DEFINED TABLE.

\begin{tabular}{|c|c|c|c|c|c|c|c|c|c|}
\hline XSID : CODE & CRWS & FR\# & YMIN & YMAX & $\mathrm{HF}$ & $\mathrm{HO}$ & VHD & EGL & WSEL \\
\hline EXITX:XS & 493.57 & 0.68 & 488.47 & $498.71 *$ & $* * * * * *$ & $* \star * * *$ & 0.69 & 495.30 & 494.61 \\
\hline FULLV : FV & 494.56 & 0.82 & 489.46 & 499.70 & 0.59 & 0.15 & 1.00 & 496.06 & 495.06 \\
\hline BRIDG : BR & 493.88 & 0.62 & 489.49 & 499.11 & 0.60 & 0.01 & 0.85 & 495.91 & 495.06 \\
\hline RDWAY : RG & 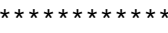 & $* * * *$ & 499.43 & $503.00 *$ & $* \star \star \star \star * *$ & $\star \star \star \star \star \star *$ & ** & ** & 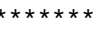 \\
\hline APPRO:AS & 495.36 & 0.95 & 490.78 & 502.07 & 0.59 & 0.34 & 1.37 & 496.85 & 495.48 \\
\hline
\end{tabular}


WSPRO OUTPUT FILE (continued)

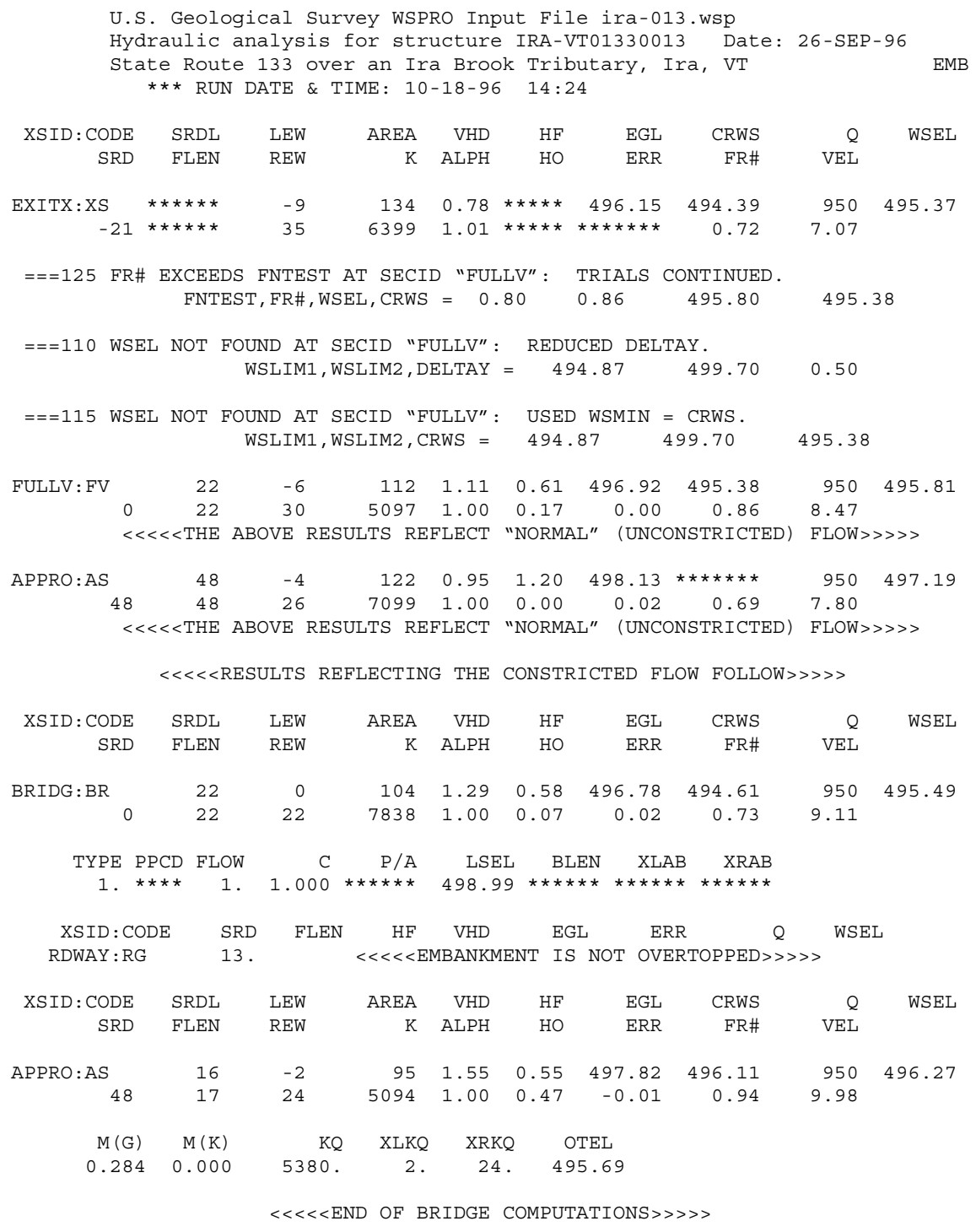

FIRST USER DEFINED TABLE.

\begin{tabular}{|c|c|c|c|c|c|c|c|c|}
\hline XSID : CODE & SRD & LEW & REW & $\mathrm{Q}$ & $\mathrm{K}$ & AREA & VEL & WSEL \\
\hline EXITX:XS & -22 . & -10 & 35. & 950. & 6399. & 134. & 7.07 & 495.37 \\
\hline FULLV : FV & 0 . & -7 . & 30. & 950. & 5097. & 112 . & 8.47 & 495.81 \\
\hline BRIDG : BR & 0 . & 0 . & 22 . & 950. & 7838. & 104. & 9.11 & 495.49 \\
\hline RDWAY : RG & \multicolumn{3}{|c|}{$13 . * \star \star \star \star \star * \star * \star * \star * \star * \star *$} & \multicolumn{3}{|c|}{ 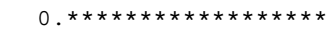 } & \multicolumn{2}{|c|}{$1.00 * * * * * * * *$} \\
\hline APPRO : AS & 48. & -3 . & 24. & 950. & 5094. & 95. & 9.98 & 496.27 \\
\hline XSID : CODE & XLKQ & XRKQ & & & & & & \\
\hline APPRO : AS & 2 . & 24 . & 538 & & & & & \\
\hline
\end{tabular}

SECOND USER DEFINED TABLE.

\begin{tabular}{|c|c|c|c|c|c|c|c|c|c|}
\hline XSID : CODE & CRWS & FR\# & YMIN & YMAX & $\mathrm{HF}$ & $\mathrm{HO}$ & VHD & EGL & WSEL \\
\hline EXITX:XS & 494.39 & 0.72 & 488.47 & $498.71 *$ & $\star \star \star \star \star \star \star *$ & $\star \star \star \star * \star$ & 0.78 & 496.15 & 495.37 \\
\hline FULLV : FV & 495.38 & 0.86 & 489.46 & 499.70 & 0.61 & 0.17 & 1.11 & 496.92 & 495.81 \\
\hline BRIDG : BR & 494.61 & 0.73 & 489.49 & 499.11 & 0.58 & 0.07 & 1.29 & 496.78 & 495.49 \\
\hline RDWAY : RG & 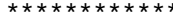 & $\star \star \star \star \star *$ & 499.43 & $503.00 *$ & $\star \star \star * \star * *$ & $\star \star \star \star \star * *$ & 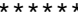 & 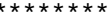 & 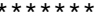 \\
\hline APPRO : AS & 496.11 & 0.94 & 490.78 & 502.07 & 0.55 & 0.47 & 1.55 & 497.82 & 496.27 \\
\hline ER & & & & & & & & & \\
\hline
\end{tabular}




\section{APPENDIX C:}

\section{BED-MATERIAL PARTICAL-SIZE DISTRIBUTION}




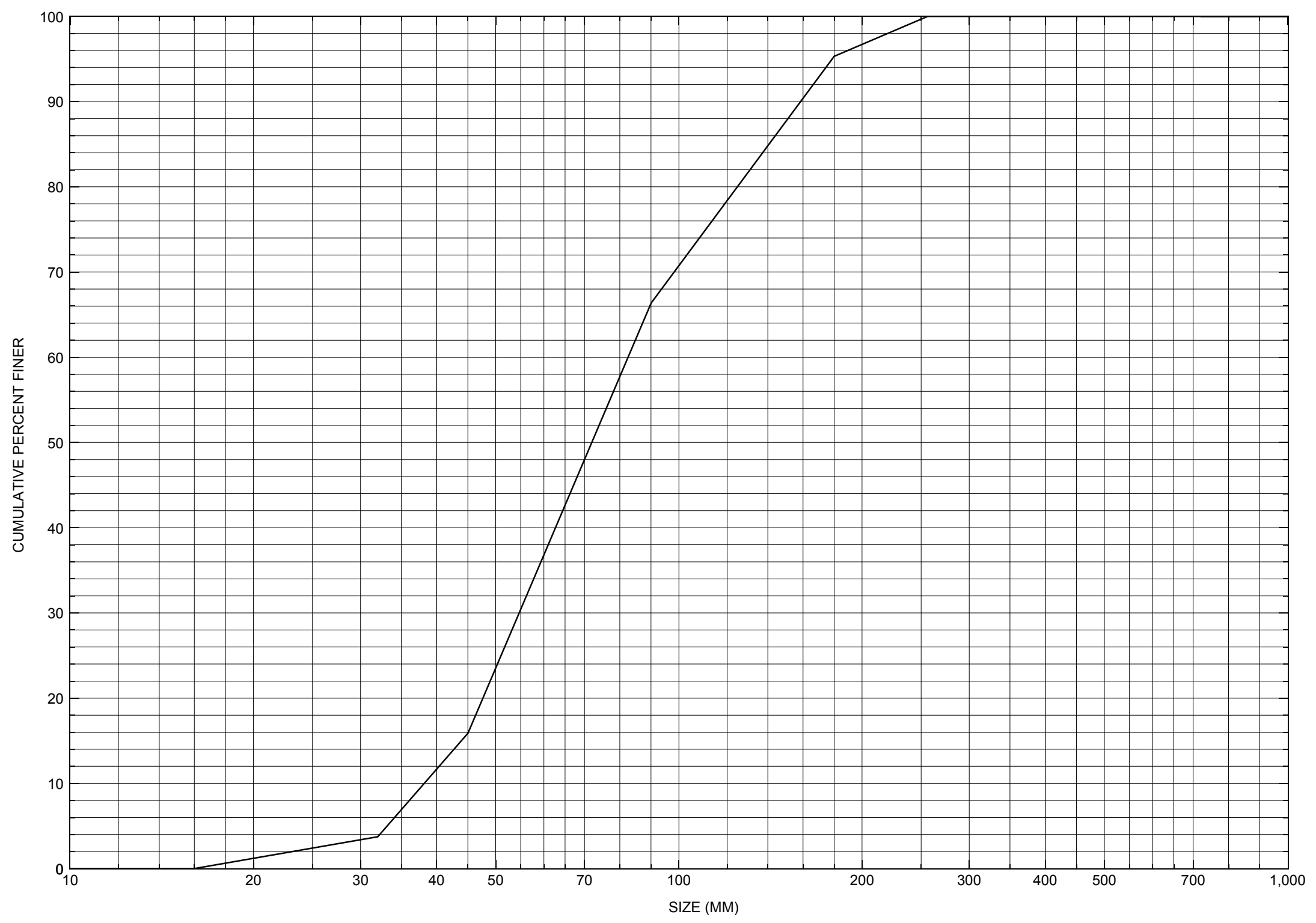

Appendix C. Bed material particle-size distribution for one pebble count transect in the channel approach of structure IRA-VT01330013, in Ira, Vermont. 


\section{APPENDIX D: \\ HISTORICAL DATA FORM}




\section{Structure Number IRA-VT01330013}

\section{General Location Descriptive}

Data collected by (First Initial, Full last name) $\mathbf{E}$. BOEHMLER

Date $(M M / D D / Y Y) \_\mathbf{0 3} / \underline{13} / \underline{95}$

Highway District Number (I - 2; nn) $\mathbf{0 3}$

Town (FIPS place code; I - 4; nnnnn) $\mathbf{3 5 4 2 5}$

Waterway (I - 6) Ira Brook Tributary

Route Number VT133

Topographic Map West Rutland

Latitude (I - 16; nnnn.n) $\mathbf{4 3 3 2 2}$
County (FIPS county code; I - 3; nnn)

Mile marker (I - 11; nnn.nnn) $\mathbf{0 0 3 1 2 0}$

Road Name (I - 7): -

Vicinity (I - 9) 4.8 MI S JCT. VT.4A

Hydrologic Unit Code: $\underline{\mathbf{0 2 0 1 0 0 0 2}}$

Longitude (i - 17; nnnnn.n) $\mathbf{7 3 0 3 6}$

\section{Select Federal Inventory Codes}

FHWA Structure Number (I - 8) $\mathbf{2 0 0 1 4 1 0 0 1 3 1 1 0 9 2}$

Maintenance responsibility $(I-21 ; n n) \quad 01$

Year built (I - 27; YYYY) 1948

Average daily traffic, ADT (I - 29; nnnnnn) 001420

Year of ADT (I - 30; YY) $\mathbf{9 2}$

Opening skew to Roadway (I - 34; nn) $\mathbf{0 5}$

Operational status $(I-41 ; X)$ A

Structure type (I - 43; nnn) 101

Approach span structure type (I - 44; nnn) $\mathbf{0 0 0}$

Number of spans (I - 45; nnn) $\mathbf{0 0 1}$

Number of approach spans (I - 46; nnnn) $\mathbf{0 0 0 0}$

Comments:

structural inspection of $9 / 10 / 93$ indicates the structure is a concrete slab type bridge. The right abutment wall is reported having areas of cracking and scaling with leakage. A concrete facing is reported to have been poured at the base of the right abutment and has areas of light to moderate scaling. The right abutment footing is exposed but not undermined. The right wingwalls are reported as having light scaling generally. The left abutment also has areas of minor cracking and scaling. The left footing is exposed and has moderate to heavy concrete scaling noted. There is an area of undermining at the downstream end about 8 feet long, up to 8" deep and penetration reaches 1 foot in places. (Continued, page 31) 


\section{Bridge Hydrologic Data}

Is there hydrologic data available? $\underline{\mathbf{N}}$ if No, type ctrl-n $h \quad$ VTAOT Drainage area $\left(m i^{2}\right)$ : -

Terrain character:

Stream character \& type: -

Streambed material:

Discharge Data (cfs):

$$
\begin{aligned}
& Q_{2.33}- \\
& Q_{50}-
\end{aligned}
$$

Record flood date $(M M / D D / Y Y)$ :

Estimated Discharge (cfs): Ice conditions (Heavy, Moderate, Light) : -

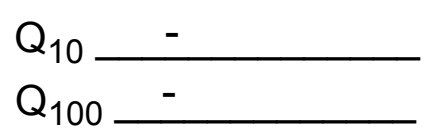

$$
\begin{aligned}
& Q_{25}- \\
& Q_{500}-
\end{aligned}
$$

Water surface elevation $(f t):-$

The stage increases to maximum highwater elevation (Rapidly, Not rapidly):

The stream response is (Flashy, Not flashy):

Describe any significant site conditions upstream or downstream that may influence the stream's stage: -

Watershed storage area (in percent): _ _ \%

The watershed storage area is: - (1-mainly at the headwaters; 2- uniformly distributed; 3-immediatly upstream oi the site)

Water Surface Elevation Estimates for Existing Structure:

\begin{tabular}{|l|l|l|l|l|l|}
\hline Peak discharge frequency & $Q_{2.33}$ & $Q_{10}$ & $Q_{25}$ & $Q_{50}$ & $Q_{100}$ \\
Water surface elevation (ft)) & - & - & - & - & - \\
Velocity (ft/sec) & - & - & - & - & - \\
\hline
\end{tabular}

Long term stream bed changes: -

Is the roadway overtopped below the $\mathrm{Q}_{100}$ ? (Yes, No, Unknown): $\mathbf{U}$ Frequency: Relief Elevation (ft): Discharge over roadway at $Q_{100}\left(f^{3} / \mathrm{sec}\right)$ :

Are there other structures nearby? (Yes, No, Unknown): $\underline{\mathbf{U}}$ Upstream distance (miles): Town: If No or Unknown, type ctrl-n os Highway No. : Structure No. : Year Built:

Clear span (ft): Clear Height $(f t)$ : Full Waterway $\left(f^{2}\right)$ : 
Downstream distance (miles): Town: Year Built:

Highway No. : Structure No. : Structure Type:

Clear span (ft): Clear Height $(f t)$ : Full Waterway $\left(f^{2}\right)$ :

Comments:

The channel is reported to make a slight turn into the structure. There is some minor streambank erosion noted downstream. The wingwalls generally are protected with light stone fill. There is vegetation noted growing on the banks both up- and downstream.

\section{USGS Watershed Data}

Watershed Hydrographic Data

Drainage area $(D A)$

Watershed storage (ST)

Bridge site elevation

Main channel length 840 $\mathrm{mi}^{2}$ 0 3.489 $10 \%$ channel length elevation $\mathbf{8 8 0}$

Main channel slope (S) 229.29 $\mathrm{ft} / \mathrm{mi}$ $\%$ mi

Lake and pond area

$\mathbf{0}$ $\mathrm{mi}^{2}$ Headwater elevation 2726 $\mathrm{ft}$ $\mathrm{ft} \quad 85 \%$ channel length elevation 1680 $\mathrm{ft}$

Watershed Precipitation Data

Average site precipitation in Average headwater precipitation in

Maximum 2yr-24hr precipitation event $(124,2)$ in

Average seasonal snowfall (Sn) $\mathrm{ft}$ 


\section{Bridge Plan Data}

Are plans available? $\mathrm{N}^{*}$ If no, type ctrl-n pl Date issued for construction (MM/YYYY):

Project Number

Minimum channel bed elevation:

Low superstructure elevation: USLAB DSLAB USRAB DSRAB Benchmark location description:

NO BENCHMARK INFORMATION

Reference Point (MSL, Arbitrary, Other): Datum (NAD27, NAD83, Other):

Foundation Type: 4

If 1: Footing Thickness

If 2: Pile Type: (1-Wood; 2-S

(1-

(1-Spreadfooting; 2-Pile; 3- Gravity; 4-Unknown)

Footing bottom elevation:

If 3 : Footing bottom elevation:
Is boring information available?

Foundation Material Type: $\mathbf{3}$

Briefly describe material at foundation bottom elevation or around piles:

NO FOUNDATION MATERIAL INFORMATION

Comments:

*Plans marked TF 30 -1962 only show deck details with no elevations. 


\section{Cross-sectional Data}

Is cross-sectional data available? $\mathbf{N}$ If no, type ctrl-n xs

Source (FEMA, VTAOT, Other)? -

Comments: NO CROSS SECTION INFORMATION

\begin{tabular}{|l|l|l|l|l|l|l|l|l|l|l|l|}
\hline Station & - & - & - & - & - & - & - & - & - & - & - \\
\hline Feature & - & - & - & - & - & - & - & - & - & - & - \\
\hline $\begin{array}{l}\text { Low cord } \\
\text { elevation }\end{array}$ & - & - & - & - & - & - & - & - & - & - & - \\
\hline $\begin{array}{l}\text { Bed } \\
\text { elevation }\end{array}$ & - & - & - & - & - & - & - & - & - & - & - \\
\hline $\begin{array}{l}\text { Low cord to } \\
\text { bed length }\end{array}$ & - & - & - & - & - & - & - & - & - & - & - \\
\hline Station & - & - & - & - & - & - & - & - & - & - & - \\
\hline Feature & - & - & - & - & - & - & - & - & - & - & - \\
\hline $\begin{array}{l}\text { Low cord } \\
\text { elevation }\end{array}$ & - & - & - & - & - & - & - & - & - & - & - \\
\hline $\begin{array}{l}\text { Bed } \\
\text { elevation }\end{array}$ & - & - & - & - & - & - & - & - & - & - & - \\
\hline $\begin{array}{l}\text { Low cord to } \\
\text { bed length }\end{array}$ & - & - & - & - & - & - & - & - & - & - & - \\
\hline
\end{tabular}

Source (FEMA, VTAOT, Other)?

Comments: NO CROSS SECTION INFORMATION

\begin{tabular}{|l|l|l|l|l|l|l|l|l|l|l|l|}
\hline Station & - & - & - & - & - & - & - & - & - & - & - \\
\hline Feature & - & - & - & - & - & - & - & - & - & - & - \\
\hline $\begin{array}{l}\text { Low cord } \\
\text { elevation }\end{array}$ & - & - & - & - & - & - & - & - & - & - & - \\
\hline $\begin{array}{l}\text { Bed } \\
\text { elevation }\end{array}$ & - & - & - & - & - & - & - & - & - & - & - \\
\hline $\begin{array}{l}\text { Low cord to } \\
\text { bed length }\end{array}$ & - & - & - & - & - & - & - & - & - & - & - \\
\hline Station & - & - & - & - & - & - & - & - & - & - & - \\
\hline Feature & - & - & - & - & - & - & - & - & - & - & - \\
\hline $\begin{array}{l}\text { Low cord } \\
\text { elevation }\end{array}$ & - & - & - & - & - & - & - & - & - & - & - \\
\hline $\begin{array}{l}\text { Bed } \\
\text { levation }\end{array}$ & - & - & - & - & - & - & - & - & - & - & - \\
\hline $\begin{array}{l}\text { Low cord to } \\
\text { bed length }\end{array}$ & - & - & - & - & - & - & - & - & - & - & - \\
\hline
\end{tabular}




\section{APPENDIX E: \\ LEVEL I DATA FORM}


U. S. Geological Survey

Bridge Field Data Collection and Processing Form

Qa/Qc Check by: CG Date: $01 / 22 / 96$

\section{Structure Number}

\section{A. General Location Descriptive}

1. Data collected by (First Initial, Full last name) M. Ivanoff

2. Highway District Number $\mathbf{0 3}$

Date $(M M / D D / Y Y) 6$

$14 / 1995$

County Rutland (021)

Mile marker $\mathbf{0 0 3 1 2 0}$

Waterway (I - 6) Ira Brook

Route Number VT 133

Town Ira (35425)

Road Name VT 133

3. Descriptive comments:

Hydrologic Unit Code: 02010002

Located 4.8 mi south from the junction of VT 133 with VT 4A.

\section{B. Bridge Deck Observations}
4. Surface cover... LBUS 4
RBUS 4
LBDS 4
RBDS 4
Overall 4

(2b us, ds,lb,rb: 1- Urban; 2- Suburban; 3- Row crops; 4- Pasture; 5- Shrub- and brushland; 6- Forest; 7- Wetland)
5. Ambient water surface... US $\underline{2}$
UB 2
DS $\underline{2}$
(1- pool; 2- riffle)

6. Bridge structure type 1 (1- single span; 2- multiple span; 3- single arch; 4- multiple arch; 5-cylindrical culvert; 6- box culvert; or 7- other)
7. Bridge length $\mathbf{2 8 . 0}$
(feet)
Span length $\underline{\mathbf{2 6 . 0}}$
(feet)
Bridge width $\underline{\mathbf{3 1 . 2}}$ (feet)

\section{Road approach to bridge:}
8. LB
RB 0
( 0 even, 1- lower, 2- higher)
9. $\mathrm{LB}$ RB 1
(1-Paved, 2- Not paved)

10. Embankment slope (run / rise in feet / foot):

US left

US right

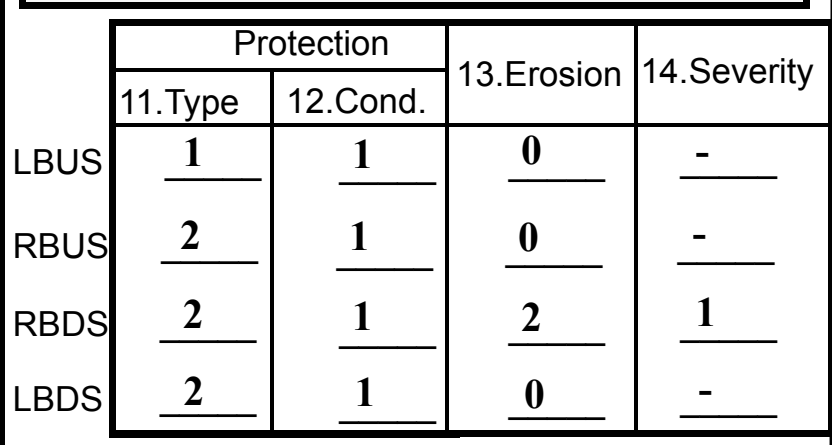

Bank protection types: 0- none; 1- < 12 inches;

2- < 36 inches; 3- < 48 inches;

4- < 60 inches; 5- wall / artificial levee

Bank protection conditions: 1- good; 2- slumped;

3- eroded; 4- failed

Erosion: 0 - none; 1- channel erosion; 2 -

road wash; 3- both; 4- other

Erosion Severity: 0 - none; 1- slight; 2- moderate;

\section{Channel approach to bridge (BF):}

15. Angle of approach: $\mathbf{1 5}$

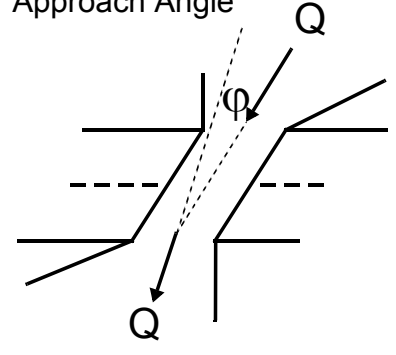

17. Channel impact zone 1:

Where? LB $(L B, R B)$

Range? 12

Channel impact zone 2:

Where? $(L B, R B)$

Range? - $\quad$ feet -

(US, UB, DS) to Impact Severity: 0- none to very slight; 1- Slight; 2-Moderate; 3- Severe feet -

16. Bridge skew: 20 Bridge Skew Angle

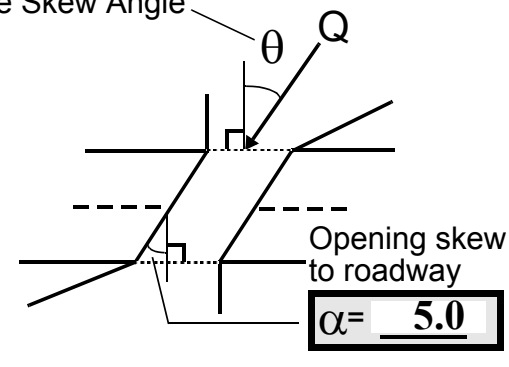

\section{Exist? $\mathbf{Y}(Y$ or $N)$}

Severity 2

, UB, DS) to $\underline{\mathbf{0} \quad \text { feet }} \underline{\mathbf{D S}}$

Exist? $\mathbf{N}(Y$ or $N)$

Severity - 
18. Bridge Type: 1a

1a- Vertical abutments with wingwalls

1 b- Vertical abutments without wingwalls

2- Vertical abutments and wingwalls, sloping embankment

Wingwalls perpendicular to abut. face

3- Spill through abutments

4- Sloping embankment, vertical wingwalls and abutments

1a with wingwalls

Wingwall angle less than $90^{\circ}$.

19. Bridge Deck Comments (surface cover variations, measured bridge and span lengths, bridge type variations, approach overflow width, etc.)

4. Within two bridge lengths the vegetation is pasture with dense tree cover on the immediate banks. Approach overflow width left road approach 23.0 feet, 170 feet from upstream left abutment.

\section{Upstream Channel Assessment}

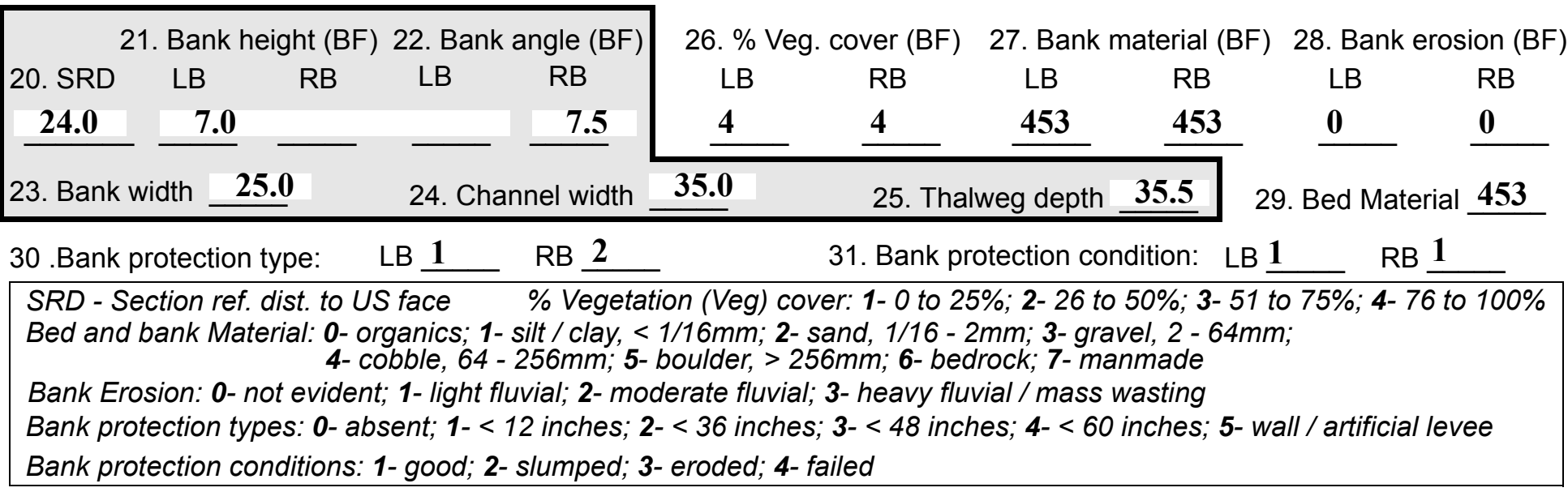

32. Comments (bank material variation, minor inflows, protection extent, etc.):

27. Bank material consists of cobbles, boulders and gravel.

29. Bed material consists of cobbles, boulders and gravel.

30. Right bank protection "stone fill" extends 20 feet from the bridge.

30. Left bank protection "stone fill" extends 18 feet from the bridge. 
33.Point/Side bar present? $\mathbf{N}(Y$ or $N$. if $N$ type ctrl-n pb)34. Mid-bar distance: -

35. Mid-bar width:

36. Point bar extent: feet (US, UB) to feet (US, UB, DS) positioned $\%$ LB to $\% \mathrm{RB}$

37. Material:

38. Point or side bar comments (Circle Point or Side; Note additional bars, material variation, status, etc.):

NO POINT BARS

39. Is a cut-bank present? $\underline{\mathbf{N}}$ (Y or if $\mathrm{N}$ type ctrl-n cb)

40. Where? (LB or $R B)$

41. Mid-bank distance: -

42. Cut bank extent: feet (US, UB) to feet (US, UB, DS)

43. Bank damage: (1- eroded and/or creep; 2- slip failure; 3- block failure)

44. Cut bank comments (eg. additional cut banks, protection condition, etc.):

NO CUT BANKS

45. Is channel scour present? $\mathbf{N}$ ( $Y$ or if $N$ type ctrl-n cs)

47. Scour dimensions: Length Width Depth : 46. Mid-scour distance: -

48. Scour comments (eg. additional scour areas, local scouring process, etc.):

NO CHANNEL SCOUR

49. Are there major confluences? $\mathbf{N}$

51. Confluence 1: Distance Confluence 2: Distance 52. Enters on Enters on 54. Confluence comments (eg. confluence name):

\section{NO MAJOR CONFLUENCES}

50. How many? -

53. Type(1- perennial; 2- ephemeral)

Type (1-perennial; 2-ephemeral) ( $L B$ or $R B)$

\section{Under Bridge Channel Assessment}

55. Channel restraint (BF)? LB 2

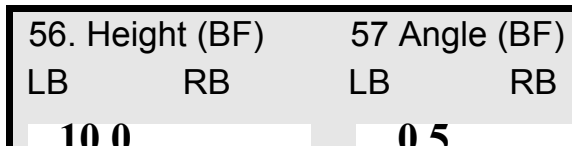

10.0 0.5 (1- natural bank; 2- abutment; 3- artificial levee)

58. Bank width (BF) 59. Channel width (Amb) -

61. Material (BF)

LB RB

\begin{tabular}{ll}
2 & 7 \\
\hline
\end{tabular}
62. Erosion (BF)

LB RB 7

60. Thalweg depth $(\mathrm{Amb}) \quad \mathbf{9 0 . 0}$

63. Bed Material -

Bed and bank Material: 0- organics; 1- silt / clay, < 1/16mm; 2- sand, 1/16 - 2mm; 3- gravel, 2 - 64mm; 4- cobble, 64 - 256mm; 5- boulder, > 256mm; 6- bedrock; 7- manmade

Bank Erosion: 0- not evident; 1- light fluvial; 2- moderate fluvial; 3- heavy fluvial / mass wasting

64. Comments (bank material variation, minor inflows, protection extent, etc.):

453

63. Bed Material consists of cobbles, boulders and gravel. 
65. Debris and Ice Is there debris accumulation?

$(Y$ or $N)$ 66. Where? $\underline{Y}$

(1- Upstream; 2- At bridge; 3- Both)

67. Debris Potential $\underline{3}$

( 1- Low; 2- Moderate; 3- High)

68. Capture Efficiency 2

(1-Low; 2- Moderate; 3- High)

69. Is there evidence of ice build-up? 1

Ice Blockage Potential $\mathbf{N}$

(1-Low; 2- Moderate; 3- High)

70. Debris and Ice Comments:

1

67. There are some trees leaning over channel and some dead trees on the banks.

68. The span is $80 \%$ of the bank width skewed to the flow.

\begin{tabular}{|l|c|c|c|c|c|c|c|c|}
\hline Abutments & $\begin{array}{c}\text { 71. Attack } \\
\angle \text { (BF) }\end{array}$ & $\begin{array}{c}\text { 72. Slope } \angle \\
\text { (Qmax) }\end{array}$ & $\begin{array}{c}\text { 73. Toe } \\
\text { loc. (BF) }\end{array}$ & $\begin{array}{c}\text { 74. Scour } \\
\text { Condition }\end{array}$ & $\begin{array}{c}75 . \text { Scour } \\
\text { depth }\end{array}$ & $\begin{array}{c}\text { 76. Exposure } \\
\text { depth }\end{array}$ & 77. Material & 78. Length \\
\hline LABUT & & $\mathbf{1 5}$ & $\mathbf{9 0}$ & $\mathbf{2}$ & $\mathbf{3}$ & $\mathbf{0 . 5}$ & $\mathbf{2 . 5}$ & $\mathbf{9 0 . 0}$ \\
\hline RABUT & $\mathbf{1}$ & $\mathbf{0}$ & $\mathbf{9 0}$ & & & $\mathbf{2}$ & $\mathbf{2}$ & $\mathbf{2 2 . 0}$ \\
\hline
\end{tabular}

Pushed: $L B$ or RB

Toe Location (Loc.): 0- even, 1- set back, 2- protrudes

Scour cond.: 0- not evident; 1- evident (comment); 2- footing exposed; 3-undermined footing; 4- piling exposed; 5- settled; 6- failed

Materials: 1- Concrete; 2- Stone masonry or drywall; 3- steel or metal; 4- wood

79. Abutment comments (eg. undermined penetration, unusual scour processes, debris, etc.):

0

2.0

1

75. For 8 feet from the downstream face, the left abutment is undermined up to 8 " deep with about 1 foot of horizontal penetration under the footing.

76. The exposure is measured from the top of the footing to the streambed.

80. Wingwalls: $\begin{array}{lllll} & & & & \\ \text { Exist? } & \text { Material? } & \text { Scour } & \text { Scour } & \text { Exposure } \\ \text { Condition? } & \text { depth? } & \text { depth? }\end{array}$

USLWW:

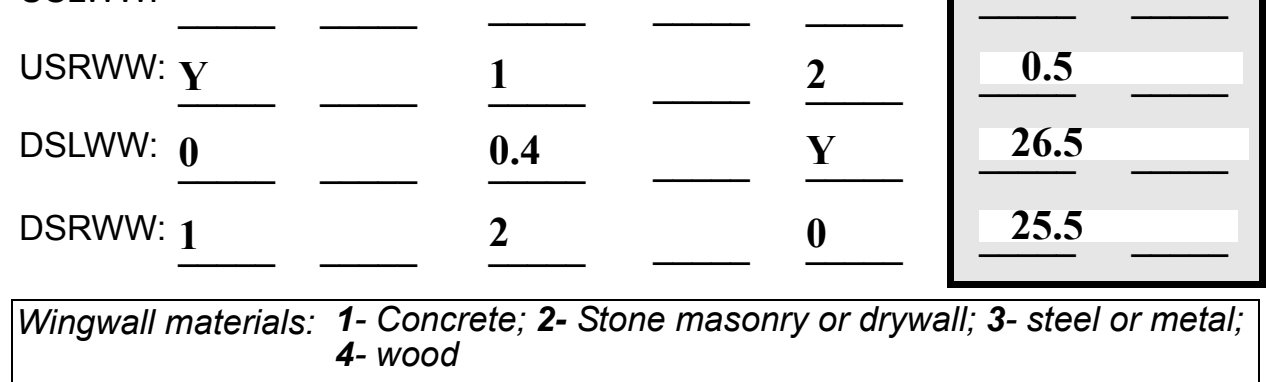

22.0

4- wood

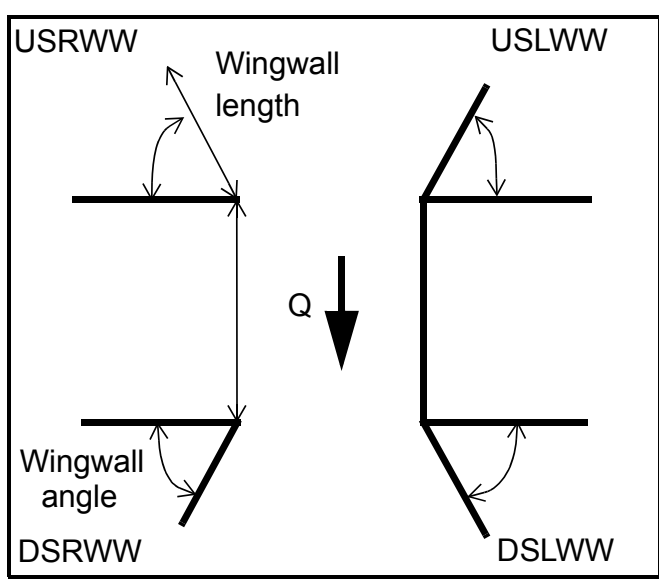

82. Bank / Bridge Protection:

\begin{tabular}{|l|l|l|l|l|l|l|l|l|}
\hline Location & USLWW & USRWW & LABUT & RABUT & LB & RB & DSLWW & DSRWW \\
\hline Type & $\mathbf{0 . 5}$ & $\mathbf{2}$ & $\mathbf{Y}$ & $\mathbf{0}$ & $\mathbf{1}$ & $\mathbf{1}$ & - & - \\
\hline Condition & $\mathbf{Y}$ & $\mathbf{0}$ & $\mathbf{1}$ & $\mathbf{1 . 8}$ & $\mathbf{1}$ & $\mathbf{1}$ & - & - \\
\hline Extent & $\mathbf{1}$ & $\mathbf{2 . 0}$ & $\mathbf{2}$ & $\mathbf{1}$ & $\mathbf{2}$ & $\mathbf{0}$ & $\mathbf{0}$ & $\mathbf{0}$ \\
\hline
\end{tabular}

Bank / Bridge protection types: 0- absent; 1- < 12 inches; 2- < 36 inches; 3- < 48 inches; 4- < 60 inches; 
83. Wingwall and protection comments (eg. undermined penetration, unusual scour processes, etc.):

-
-
0
-
-
2
1
1
2
1
1

Piers:

84. Are there piers? 80. (Y or if $N$ type ctrl-n pr)

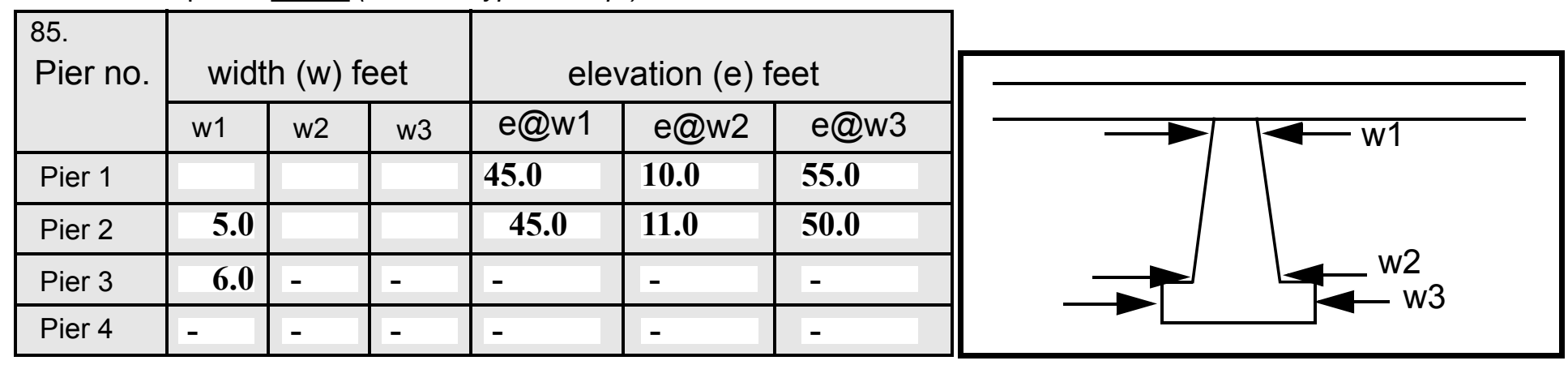

\begin{tabular}{|l|l|l|l|l|}
\hline Level 1 Pier Descr. & \multicolumn{1}{|c|}{1} & \multicolumn{1}{|c|}{2} & \multicolumn{1}{|c|}{3} & \multicolumn{1}{|c|}{} \\
\hline 86. Location (BF) & All & sure & ment & - \\
\hline 87. Type & wing & dept & s. & - \\
\hline 88. Material & walls & hs of & & - \\
\hline 89. Shape & have & foot- & & - \\
\hline 90. Inclined? & been & ings & & - \\
\hline 91. Attack $\angle$ (BF) & pro- & are & & - \\
\hline 92. Pushed & tecte & at & & - \\
\hline 93. Length (feet) & - & - & - & - \\
\hline 94. \# of piles & d & the & & - \\
\hline 95. Cross-members & with & junc- & & - \\
\hline 96. Scour Condition & stone & tions & & - \\
\hline 97. Scour depth & fill. & with & & - \\
\hline 98. Exposure depth & Expo & abut & N & - \\
\hline
\end{tabular}

LFP, LTB, LB, MCL, MCM, MCR, RB, RTB, RFP

1- Solid pier, 2- column, 3- bent

1-Wood; 2- concrete; 3- metal; 4- stone

1- Round; 2- Square; 3- Pointed

Y-yes; $N$ - no

$L B$ or $R B$

0- none; 1- laterals; 2- diagonals; 3- both

0- not evident; 1- evident (comment);

2- footing exposed; 3- piling exposed;

4- undermined footing; 5- settled; 6 - failed 
99. Pier comments (eg. undermined penetration, protection and protection extent, unusual scour processes, etc.):

-
-
-
-
-
-
-
-
-

100.

\section{E. Downstream Channel Assessment}

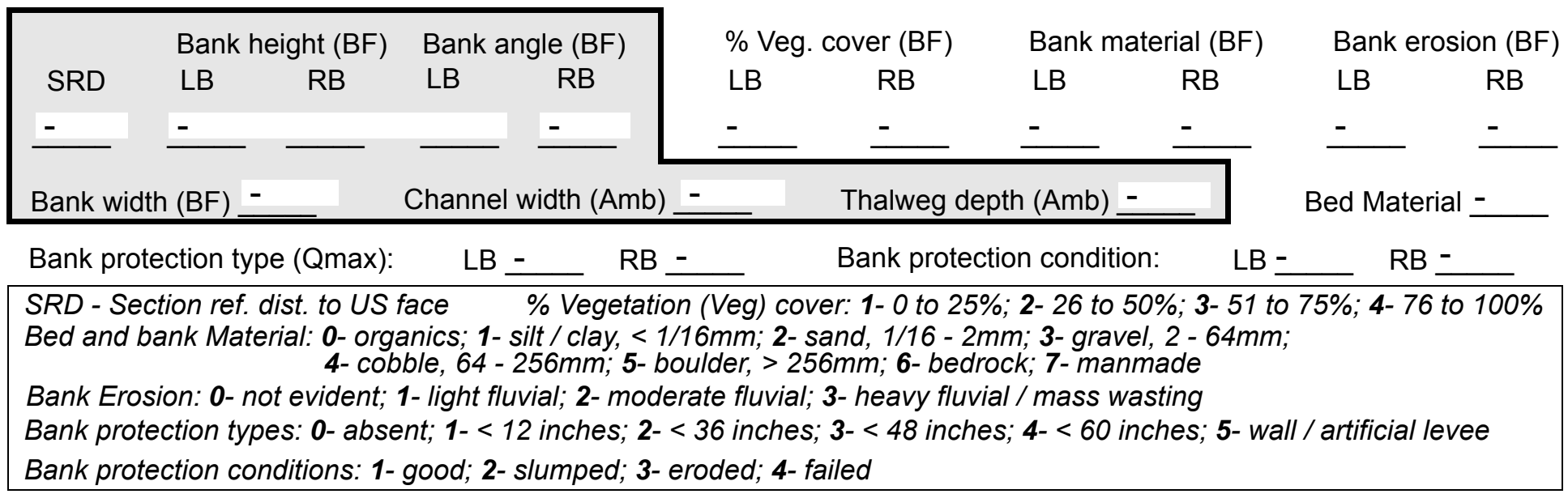

Comments (eg. bank material variation, minor inflows, protection extent, etc.):

-
-
-
-
-
-
-
-
-
-
-
-
-
-
-

101. Is a drop structure present? $\mathbf{N}$ ( $Y$ or $N$, if $N$ type ctrl-n ds) 102. Distance: __ feet 103. Drop: -_ feet 104. Structure material: $\mathbf{O}$ (1- steel sheet pile; 2- wood pile; 3- concrete; 4- other) 105. Drop structure comments (eg. downstream scour depth):

PIERS 
106. Point/Side bar present? (Y or $N$. if $N$ type ctrl-n pb)Mid-bar distance:

Mid-bar width:

Point bar extent: feet 4

(US, UB, DS) to 4 feet $\underline{453}$ (US, UB, DS) positioned 1 $\%$ LB to $\mathbf{4 5 3} \%$ RB

Material: 1

Point or side bar comments (Circle Point or Side; note additional bars, material variation, status, etc.):

2

2

453

2

Is a cut-bank present? 2 (Y or if $N$ type ctrl-n $c b)$ Where? $\underline{1}$ (LB or RB) Mid-bank distance: 1 Cut bank extent: Ban feet $\underline{\mathbf{k}}$ (US, UB, DS) to mate feet rial $(U S, U B, D S$ )

Bank damage: con (1- eroded and/or creep; 2- slip failure; 3- block failure)

Cut bank comments (eg. additional cut banks, protection condition, etc.):

sists of cobbles, boulders, gravel and silt/clay.

Bed material consists of cobbles, boulders and gravel.

Bank protection extends 18 feet along both banks from the bridge face.

Is channel scour present? ( $Y$ or if $N$ type ctrl-n cs)

Mid-scour distance:

Scour dimensions: Length Width Depth:

Positioned $\%$ LB to $\% \mathrm{RB}$

Scour comments (eg. additional scour areas, local scouring process, etc.):

Are there major confluences? $\mathbf{N}$ ( $Y$ or if $N$ type ctrl-n $m c)$

Confluence 1: Distance NO

Confluence 2: Distance $\underline{\text { STR }}$ Enters on $\underline{\mathbf{D R}}$ (LB or RB)

Enters on $\underline{\mathbf{U C}}$ ( $L B$ or $R B)$

Confluence comments (eg. confluence name):

RE

\section{F. Geomorphic Channel Assessment}

107. Stage of reach evolution
1- Constructed

2- Stable

3- Aggraded

4- Degraded

5- Laterally unstable

6- Vertically and laterally unstable
How many? -

Type OP (1-perennial; 2- ephemeral) Type TU (1- perennial; 2- ephemeral) 
108. Evolution comments (Channel evolution not considering bridge effects; See HEC-20, Figure 1 for geomorphic descriptors):

Y
35
4
30
DS
45
DS
0
45
34 


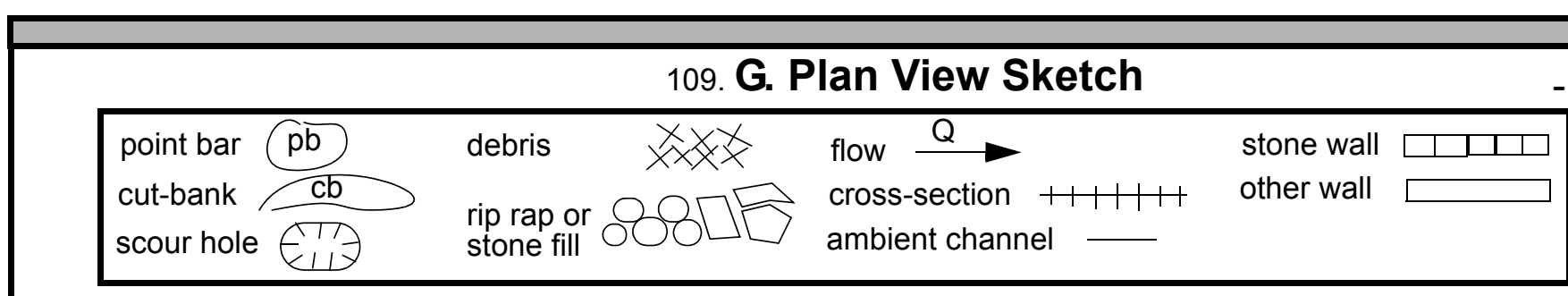


APPENDIX F:

SCOUR COMPUTATIONS 
SCOUR COMPUTATIONS

\begin{tabular}{|c|c|c|c|}
\hline & Town : & \multirow{3}{*}{$\begin{array}{l}\text { Ira } \\
\text { Rutland }\end{array}$} \\
\hline Road Number: $\quad$ VT 133 & & County: & \\
\hline Ira Brook Tributa & & & \\
\hline Initials EMB & Checked: & SAO & \\
\hline \multicolumn{4}{|c|}{ Analysis of contraction scour, live-bed or clear water? } \\
\hline \multicolumn{2}{|c|}{$\begin{array}{l}\text { Critical Velocity of Bed Material (converted } \\
\mathrm{VC}=11.21^{*} \mathrm{Y}^{\wedge} 0.1667 * \mathrm{D} 50^{\wedge} 0.33 \text { with } \mathrm{Ss}=2.65 \\
\text { (Richardson and others, } 1995, \mathrm{p} .28, \text { eq. 16) }\end{array}$} & to Ens & h \\
\hline \multicolumn{4}{|l|}{ Approach Section } \\
\hline Characteristic & $100 \mathrm{yr}$ & $500 \mathrm{yr}$ & other Q \\
\hline Total discharge, cfs & 700 & 950 & 0 \\
\hline Main Channel Area, ft2 & 75 & 95 & 0 \\
\hline Left overbank area, ft2 & 0 & 0 & 0 \\
\hline Right overbank area, ft2 & 0 & 0 & 0 \\
\hline Top width main channel, ft & 25 & 27 & 0 \\
\hline Top width L overbank, ft & 0 & 0 & 0 \\
\hline Top width $\mathrm{R}$ overbank, ft & 0 & 0 & 0 \\
\hline D50 of channel, ft & 0.237 & 0.237 & 0 \\
\hline D50 left overbank, ft & 0 & 0 & 0 \\
\hline D50 right overbank, ft & 0 & 0 & 0 \\
\hline $\mathrm{Y}^{1}$, average depth, $\mathrm{MC}$, ft & 3.0 & 3.5 & ERR \\
\hline Y1, average depth, LOB, ft & ERR & ERR & ERR \\
\hline y1, average depth, ROB, ft & ERR & ERR & $\mathrm{ERR}$ \\
\hline Total conveyance, approach & 3668 & 5093 & 0 \\
\hline Conveyance, main channel & 3668 & 5093 & 0 \\
\hline Conveyance, LOB & 0 & 0 & 0 \\
\hline Conveyance, ROB & 0 & 0 & 0 \\
\hline Percent discrepancy, conveyance & 0.0000 & 0.0000 & ERR \\
\hline Qm, discharge, MC, cfs & 700.0 & 950.0 & ERR \\
\hline Q1, discharge, LOB, Cfs & 0.0 & 0.0 & ERR \\
\hline Qr, discharge, ROB, cfs & 0.0 & 0.0 & ERR \\
\hline $\mathrm{Vm}$, mean velocity $\mathrm{MC}$, ft/s & 9.3 & 10.0 & ERR \\
\hline Vl, mean velocity, LOB, ft/s & ERR & ERR & ERR \\
\hline Vr, mean velocity, ROB, ft/s & ERR & ERR & ERR \\
\hline Vc-m, crit. velocity, MC, ft/s & 8.3 & 8.6 & $\mathrm{~N} / \mathrm{A}$ \\
\hline Vc-l, crit. velocity, LOB, ft/s & $\mathrm{N} / \mathrm{A}$ & $\mathrm{N} / \mathrm{A}$ & $\mathrm{N} / \mathrm{A}$ \\
\hline Vc-r, crit. velocity, ROB, ft/s & $\mathrm{N} / \mathrm{A}$ & $\mathrm{N} / \mathrm{A}$ & $\mathrm{N} / \mathrm{A}$ \\
\hline \multicolumn{4}{|l|}{ Results } \\
\hline Live-bed(1) or Clear-Water (0) Cont & action $\mathrm{SC}$ & ur? & N \\
\hline
\end{tabular}




\begin{tabular}{|c|c|c|c|c|c|c|}
\hline \multicolumn{7}{|c|}{$\begin{array}{l}\text { Laursen's Live Bed Contraction Scour } \\
\mathrm{y}^{2 / \mathrm{y} 1}=(\mathrm{Q} 2 / \mathrm{Q} 1)^{\wedge}(6 / 7) *(\mathrm{~W} 1 / \mathrm{W} 2)^{\wedge}(\mathrm{k} 1) \\
\mathrm{ys}=\mathrm{y} 2-\mathrm{y} \text { bridge } \\
\text { (Richardson and others, 1995, p. } 30, \text { eq. } 17 \text { and } 18)\end{array}$} \\
\hline \multicolumn{4}{|c|}{ Approach } & \multicolumn{3}{|l|}{ Bridge } \\
\hline Characteristic & $100 \mathrm{yr}$ & $500 \mathrm{yr}$ & Other $Q$ & $100 \mathrm{yr}$ & $500 \mathrm{yr}$ & Other $Q$ \\
\hline Q1, discharge, cfs & 700 & 950 & 0 & 700 & 950 & 0 \\
\hline Total conveyance & 3668 & 5093 & 0 & 6818 & 7828 & 0 \\
\hline Main channel conveyance & 3668 & 5093 & 0 & 6818 & 7828 & 0 \\
\hline Main channel discharge & 700 & 950 & ERR & 700 & 950 & ERR \\
\hline Area - main channel, ft 2 & 75 & 95 & 0 & 94.9 & 104.2 & 0 \\
\hline (W1) channel width, ft & 25 & 27 & 0 & 21.8 & 21.8 & 0 \\
\hline (Wp) cumulative pier width, ft & 0 & 0 & 0 & 0 & 0 & 0 \\
\hline w1, adjusted bottom width(ft) & 25 & 27 & 0 & 21.8 & 21.8 & 0 \\
\hline D50, ft & 0.237 & 0.237 & 0.237 & $<--$ D50: & $72.2 \mathrm{~mm}$ & \\
\hline w, fall velocity, ft/s (p. 32) & 2 & 2 & 0 & & & \\
\hline $\begin{array}{l}\text { Y, ave. depth flow, ft } \\
\text { S1, slope EGL }\end{array}$ & $\begin{array}{l}3.00 \\
0.024\end{array}$ & $\begin{array}{l}3.52 \\
0.025\end{array}$ & $\begin{array}{l}\mathrm{N} / \mathrm{A} \\
0\end{array}$ & 4.35 & 4.78 & ERR \\
\hline$P$, wetted perimeter, $M C$, ft & 27 & 30 & 0 & & & \\
\hline R, hydraulic Radius, ft & 2.778 & 3.167 & ERR & & & \\
\hline $\mathrm{V}^{*}$, shear velocity, ft/s & 1.465 & 1.597 & $\mathrm{~N} / \mathrm{A}$ & & & \\
\hline $\mathrm{V} * / \mathrm{w}$ & 0.733 & 0.798 & ERR & & & \\
\hline $\begin{array}{l}\text { Bed transport coeff., } \mathrm{k} 1,(0.59 \text { if } \\
\mathrm{k} 1\end{array}$ & $\begin{array}{l}\mathrm{V} * / \mathrm{W}<0.5 \\
0.64\end{array}$ & $\begin{array}{l}0.64 \text { if } \\
0.64\end{array}$ & $\begin{array}{l}5<\mathrm{V} * / \mathrm{w}<2 \\
0\end{array}$ & ; 0.69 if & $\mathrm{V} * / \mathrm{w}>2.0$ & p. 33 ) \\
\hline $\mathrm{y}^{2}$, depth in contraction, ft & 3.27 & 4.03 & ERR & & & \\
\hline ys, scour depth, ft (y2-y_bridge) & -1.08 & -0.75 & $\mathrm{~N} / \mathrm{A}$ & & & \\
\hline \multicolumn{7}{|l|}{ ARMORING } \\
\hline D90 & 0.519 & 0.519 & 0 & & & \\
\hline D95 & 0.586 & 0.586 & 0 & & & \\
\hline Critical grain size, Dc, ft & 0.2561 & 0.3759 & ERR & & & \\
\hline Decimal-percent coarser than DC & 0.442 & 0.234 & 0 & & & \\
\hline depth to armoring, ft & 0.97 & 3.69 & ERR & & & \\
\hline
\end{tabular}




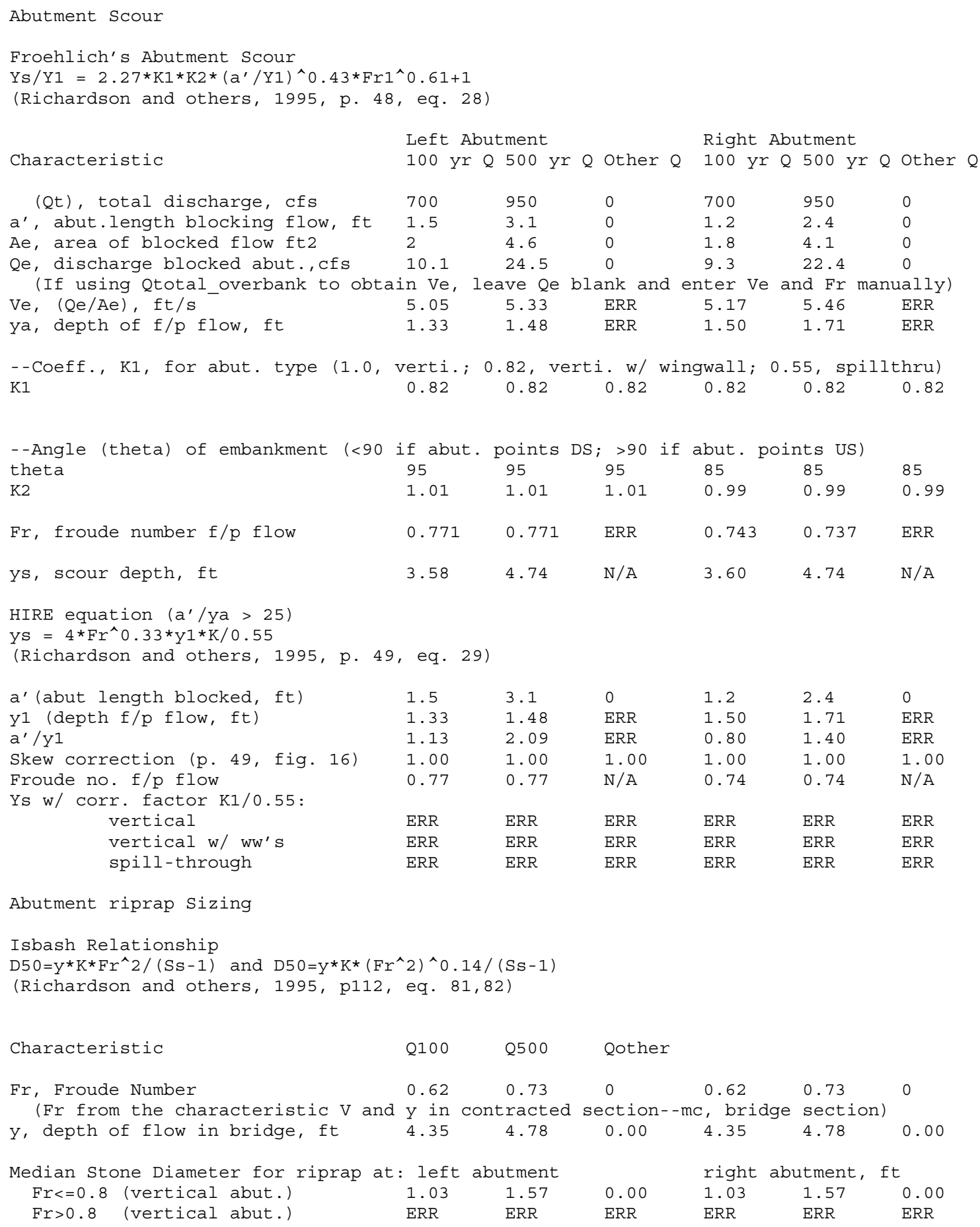

